\title{
1998 Assessment of Undiscovered Deposits of Gold, Silver, Copper, Lead, and Zinc in the United States
}

U.S. GEOLOGICAL SURVEY CIRCULAR 1178

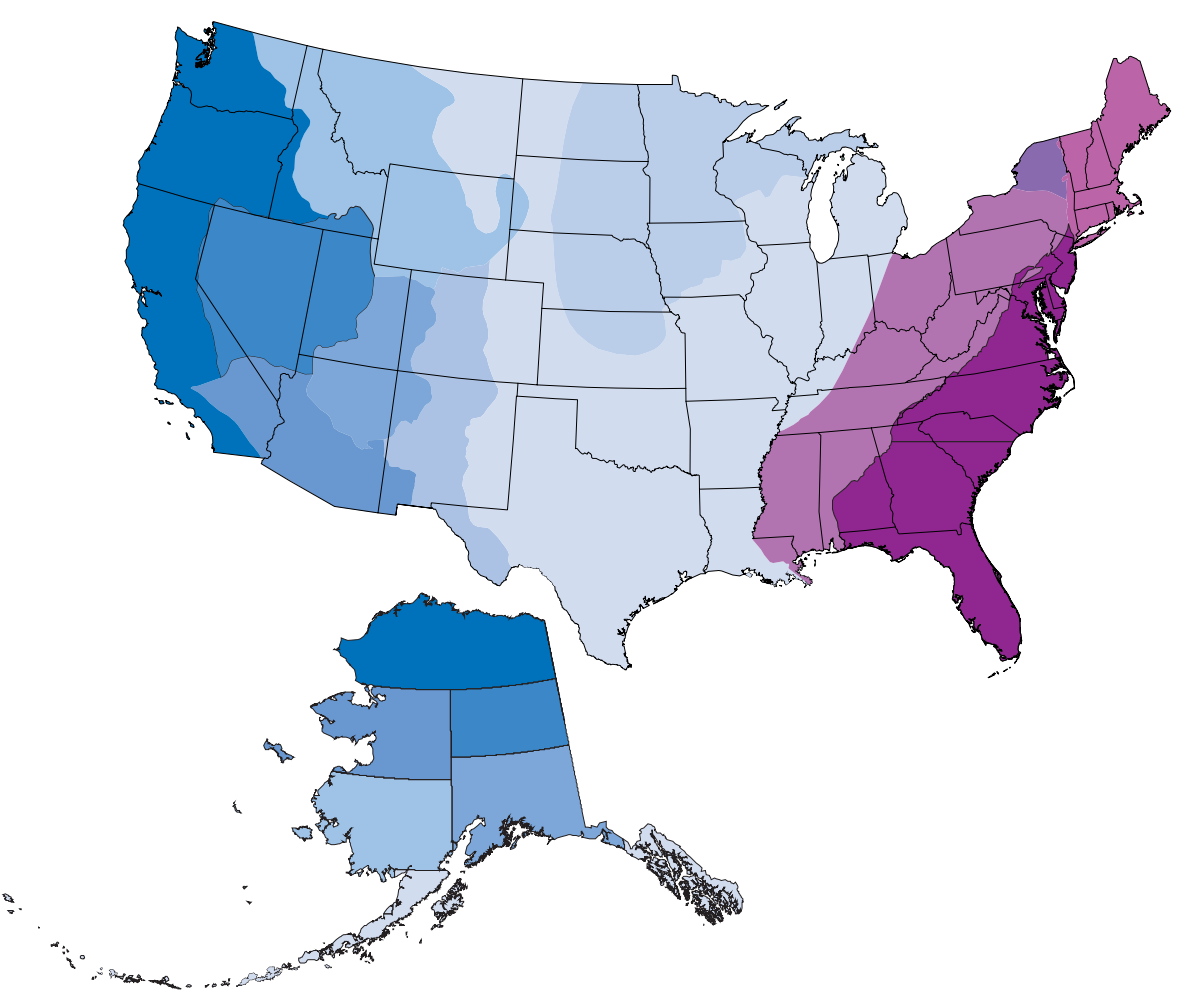




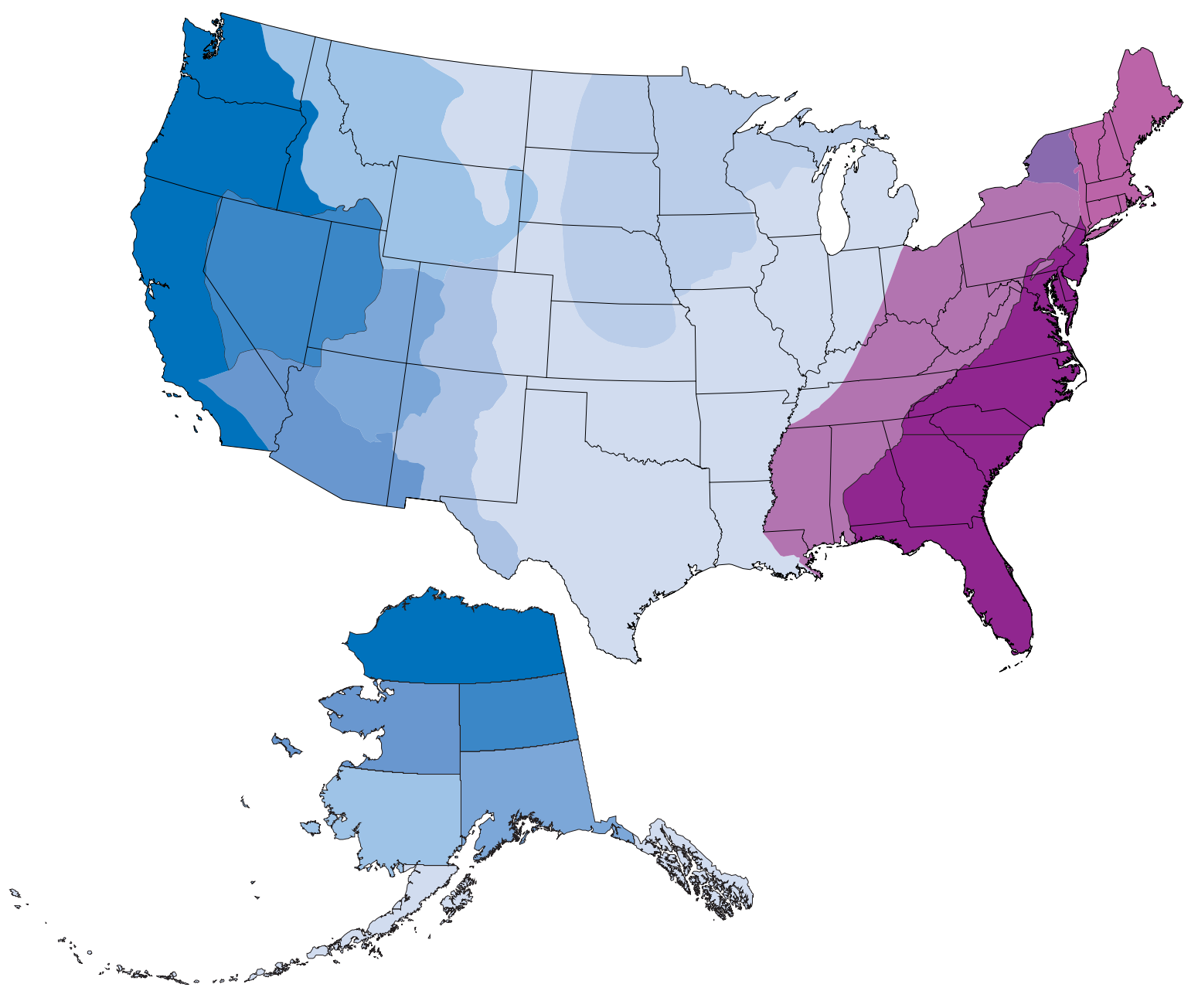

Region 1, Northern Appalachian Mountains

Region 11, Great Basin

Region 2, Adirondack Mountains

Region 12, Southern Basin and Range

Region 3, Southern Appalachian Mountains

Region 13, Brooks Range

Region 4, East-central

Region 14, East-central Alaska

Region 5, Great Plains

Region 15, West-central Alaska

Region 6, Lake Superior

Region 16, Southeastern Alaska

Region 7, Nothern Rocky Mountains

Region 17, South-central Alaska

Region 8, Central and Southern Rocky Mountains

Region 18, Southwestern Alaska

Region 9, Colorado Plateau

Region 19, Alaska Peninsula and Aleutian Islands

Region 10, Pacific Coast

Cover. Geographic regions assessed in this report. See figure 3 for region numbers. 


\section{Assessment of Undiscovered Deposits of Gold, Silver, Copper, Lead, and Zinc in the United States}

By the U.S. Geological Survey National Mineral Resource Assessment Team

\section{U.S. GEOLOGICAL SURVEY CIRCULAR 1178}




\section{U.S. DEPARTMENT OF THE INTERIOR BRUCE BABBITT, Secretary}

\section{U.S. GEOLOGICAL SURVEY}

CHARLES G. GROAT, Director

UNITED STATES GOVERNMENT PRINTING OFFICE, WASHINGTON : 2000

Published in the Eastern Region, Reston, Va.

Manuscript approved for publication February 17, 1999.

Any use of trade, product, or firm names in this publication is for descriptive purposes only and does not imply endorsement by the U.S. Government.

Free on application to

U.S. Geological Survey

Information Services

Box 25286, Federal Center

Denver, C0 80225

or call the toll-free telephone number

1-888-ASK-USGS

Library of Congress Cataloging in Publication Data

U.S. Geological Survey National Mineral Resource Assessment Team. 1998 assessment of undiscovered deposits of gold, silver, copper, lead, and zinc in the United States/ by the U.S. Geological Survey National Mineral Resource Assessment Team.

p. $\quad$ cm.-(U.S. Geological Survey circular; 1178)

Includes bibliographical references.

1. Mines and mineral resources—United States. 2. Ore-deposits—United States. I. Series

TN23.U57 1999

$553.4^{\prime} 0973-\mathrm{dc} 21$ 


\section{CONTENTS}

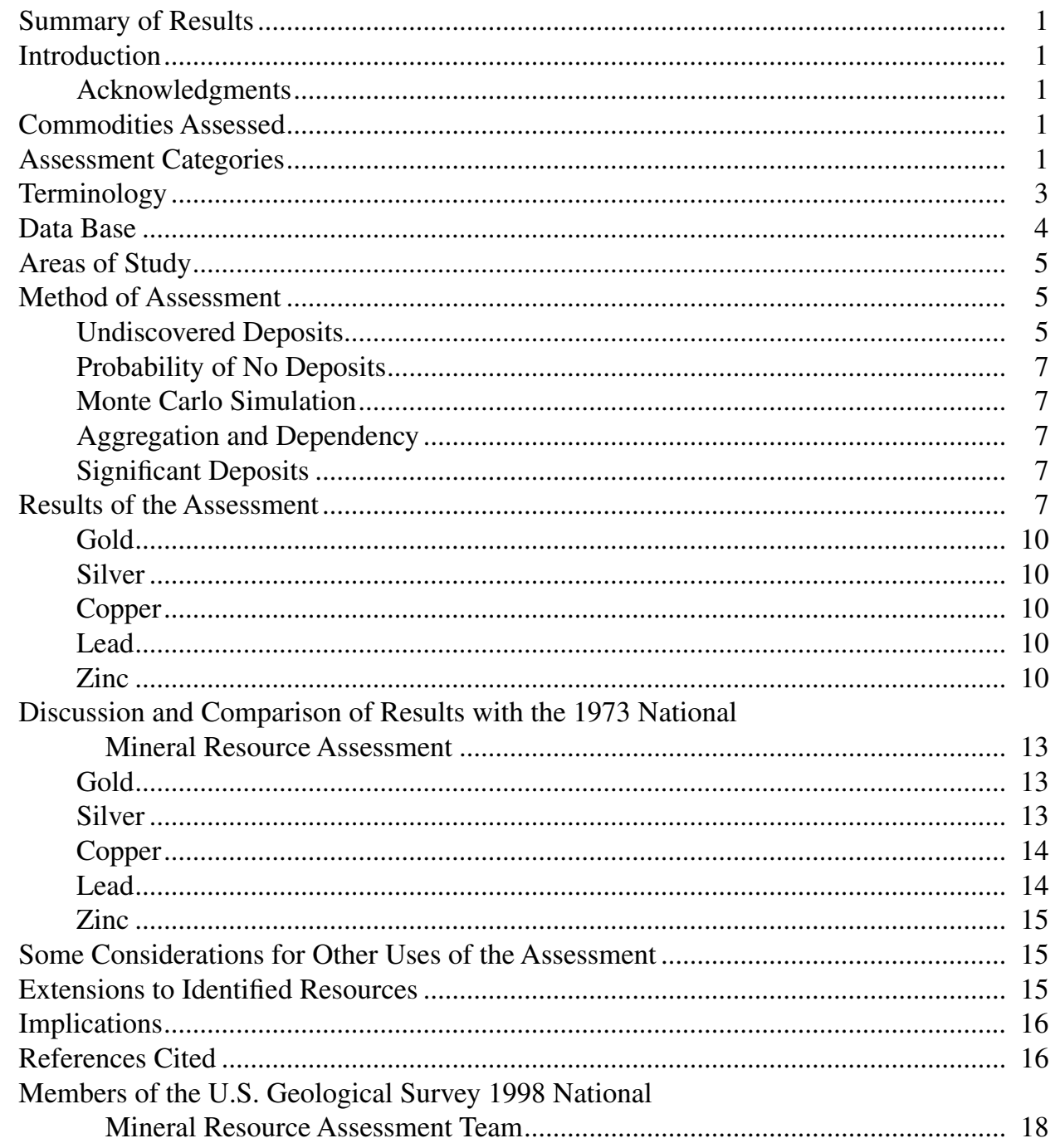

\section{COMPACT DISC}

$$
\text { [In pocket] }
$$

1998 Assessment of Undiscovered Deposits of Gold, Silver, Copper, Lead, and Zinc in the United States-CD-ROM Containing Circular Report, Data Base, and Graphical Display Program 


\section{FIGURES}

1. Pie charts showing estimated resources and past production of gold, silver, copper, lead, and zinc in the United States.

2. Diagram showing mineral resource classification used in this report ............................................................ 3

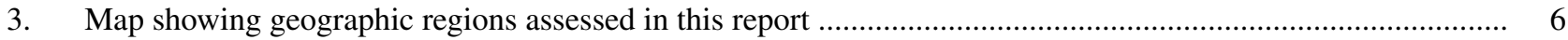

4-8. Pie charts showing-

4. Gold in undiscovered mineral deposits

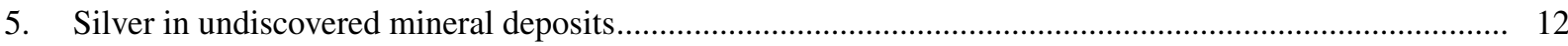

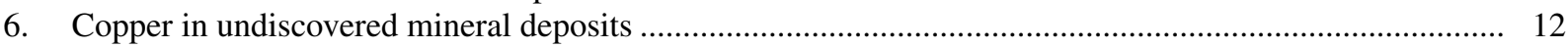

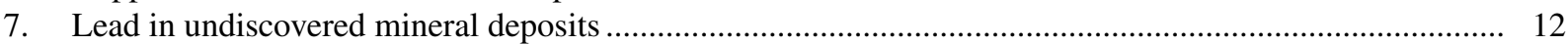

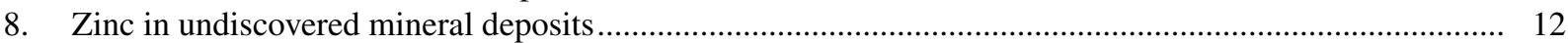

\section{TABLES}

1. Estimates of undiscovered deposits, identified resources, past production, and discovered resources of gold, silver, copper, lead, and zinc in the United States

2. Deposit models and their descriptions and major metals used in quantitative assessment of 305 of the 447 permissive tracts delineated in the 1998 National Mineral Resource Assessment ......

3. Estimates of contained metal in undiscovered deposits in the United States.....

4. Summary of identified and hypothetical copper resources in the United States, 1973.

5. Summary of speculative copper resources in the United States, 1973

\section{METRIC CONVERSION FACTORS}

For readers who wish to convert measurements from the metric system of units to the inch-pound system of units, the conversion factors are listed below:

\begin{tabular}{rll}
\hline Multiply & By & To obtain \\
\hline gram $(\mathrm{g})$ & 0.03215 & ounce (troy) \\
metric ton $(\mathrm{t})$ & 1.102 & short ton \\
kilometer $(\mathrm{km})$ & 0.6214 & miles \\
\hline
\end{tabular}

Note: Throughout this report, the amounts of gold and silver are expressed in metric tons; the amounts of copper, lead, and zinc are expressed in thousand metric tons (kilotons). 


\title{
1998 Assessment of Undiscovered Deposits of Gold, Silver, Copper, Lead, and Zinc in the United States
}

\author{
By the U.S. Geological Survey National Mineral Resource Assessment Team
}

\section{SUMMARY OF RESULTS}

This report summarizes the results of the 1998 National Mineral Resource Assessment that estimated the gold, silver, copper, lead, and zinc in undiscovered deposits in the United States. This project also estimated the identified resources and past production of these five metals. Assessment results include the following:

- It is estimated that 18,000 metric tons (t) of gold, $460,000 \mathrm{t}$ of silver, 290,000 kilotons $(\mathrm{kt})$ of copper, $85,000 \mathrm{kt}$ of lead, and 210,000 kt of zinc are in undiscovered deposits minable with existing technology.

- In addition, it is estimated that $15,000 \mathrm{t}$ of gold, $160,000 \mathrm{t}$ of silver, $260,000 \mathrm{kt}$ of copper, $51,000 \mathrm{kt}$ of lead, and $55,000 \mathrm{kt}$ of zinc remain in identified resources.

- Past production from the largest identified resources of gold, silver, copper, lead, and zinc is estimated to be 12,000 $\mathrm{t}$ of gold, 170,000 $\mathrm{t}$ of silver, 91,000 kt of copper, 41,000 kt of lead, and 44,000 kt of zinc. These deposits account for about 99 percent of cumulative domestic production in the United States.

Estimated total resources of gold, silver, copper, lead, and zinc in the United States are listed in table 1 and shown in figure 1 .

\section{INTRODUCTION}

How much of our Nation's total mineral wealth has already been discovered? How much is left? These are important questions, and discovering the answers to them is an ongoing part of the mission of the U.S. Geological Survey (USGS). To address these questions, the USGS undertook to estimate, for the first time in probabilistic terms, the amounts of gold, silver, copper, lead, and zinc in undiscovered deposits believed to exist 1 kilometer $(\mathrm{km})$ or less below the surface of the ground in the United States. This effort has resulted in the 1998 National Mineral Resource Assessment.

As the Nation's population grows and its economy matures, greater attention is being paid to such issues as land use and environmental quality, as well as to sustainability of mineral supplies to provide for the needs of future generations. National Mineral Resource Assessments provide a framework for addressing these issues by monitoring the continuing depletion of the Nation's nonrenewable mineral wealth and by contributing information required to manage resource extraction while minimizing consequent environmental effects. For responsible stewardship of the Nation's lands and resources, it is important to know in which areas future mineral resources may be located and how much metal such resources might contain (McCammon and Briskey, 1992).

\section{ACKNOWLEDGMENTS}

The USGS wishes to thank numerous individuals in industry, academia, and State geological organizations for their help. The State Geologists of many of the States were particularly helpful in reviewing material that related to the significant deposits in their States.

\section{COMMODITIES ASSESSED}

The commodities gold, silver, copper, lead, and zinc were chosen as the subject for this National Mineral Resource Assessment because, after iron and aluminum, they are the most valuable metals in our economy. These commodities have been produced widely and extensively. They also tend to occur together in nature, thereby introducing efficiencies in the estimation of undiscovered resources. Other mineral commodities may be the subject of future assessments.

\section{ASSESSMENT CATEGORIES}

The resource classification used in this report is illustrated in figure 2, a modified "McKelvey diagram" (McKelvey, 1972). Resources are classified along two axes-geologic certainty that the resource exists and economic feasibility of their development. The degree of geologic certainty decreases to the right, and the degree of economic feasibility decreases downward. Cumulative past 
Table 1. Estimates of undiscovered deposits, identified resources, past production, and discovered resources of gold, silver, copper, lead, and zinc in the United States.

[Undiscovered deposits, deposits believed to exist 1 kilometer or less below the surface of the ground within a geologically defined area; identified resources, resources whose location, grade, quality, and quantity are known or estimated from specific geologic evidence. Totals rounded to two significant figures]

\begin{tabular}{|c|c|c|c|c|c|}
\hline Category & $\begin{array}{l}\text { Gold } \\
\text { (tons) }\end{array}$ & $\begin{array}{l}\text { Silver } \\
\text { (tons) }\end{array}$ & $\begin{array}{c}\text { Copper } \\
\text { (kilotons) }\end{array}$ & $\begin{array}{c}\text { Lead } \\
\text { (kilotons) }\end{array}$ & $\begin{array}{c}\text { Zinc } \\
\text { (kilotons) }\end{array}$ \\
\hline $\begin{array}{l}\text { Undiscovered U.S. deposits, } \\
\text { estimated - }\end{array}$ & 18,000 & 460,000 & 290,000 & 85,000 & 210,000 \\
\hline $\begin{array}{l}\text { Identified U.S. resources }{ }^{1}------- \\
\text { Past U.S. production------------- }\end{array}$ & $\begin{array}{l}15,000 \\
12,000\end{array}$ & $\begin{array}{l}160,000 \\
170,000\end{array}$ & $\begin{array}{r}260,000 \\
91,000\end{array}$ & $\begin{array}{l}51,000 \\
41,000\end{array}$ & $\begin{array}{l}55,000 \\
44,000\end{array}$ \\
\hline Discovered U.S. resources $^{1}$---- & 27,000 & 330,000 & 350,000 & 92,000 & 99,000 \\
\hline
\end{tabular}

${ }^{1}$ Estimates from Long and others (1998). Discovered U.S. resources are the sum of identified U.S. resources and past U.S. production.
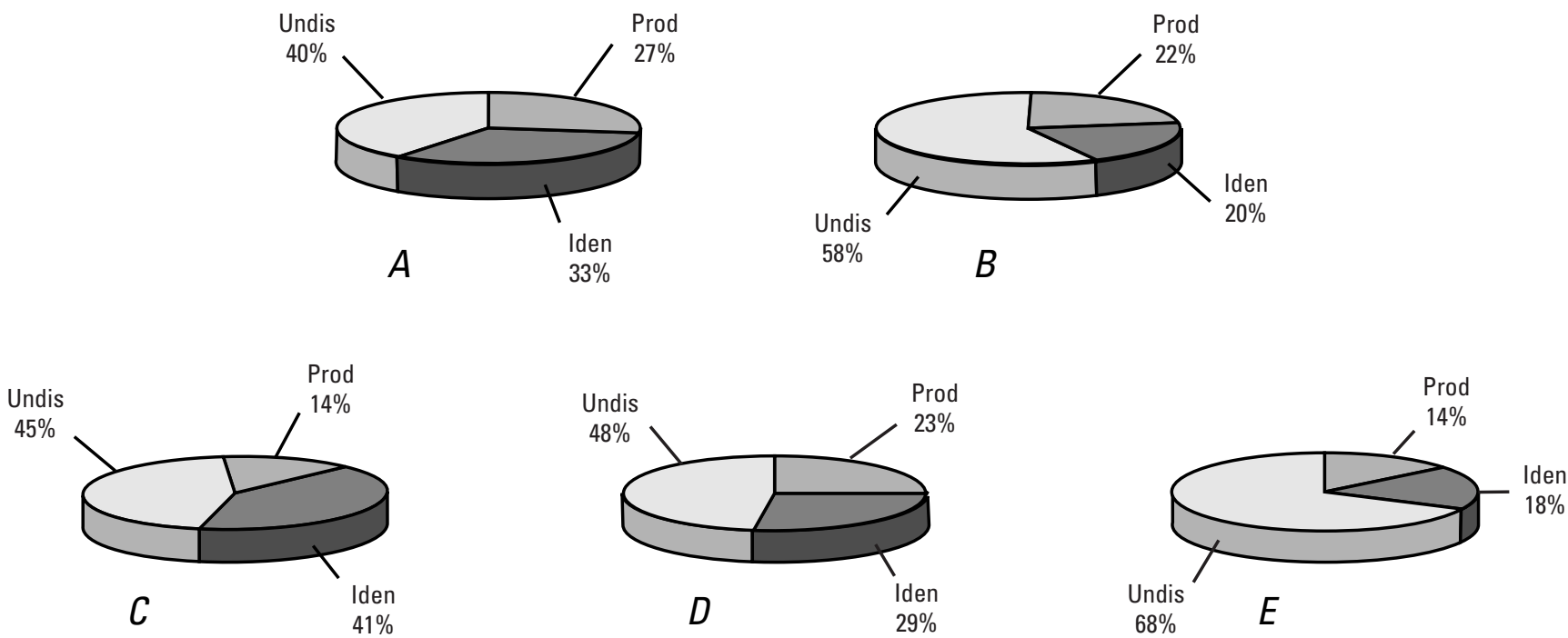

Figure 1. Estimated resources and past production (as percentage of estimated total resources) of gold, silver, copper, lead, and zinc in the United States. $A$, gold; $B$, silver; $C$, copper; $D$, lead; $E$, zinc. Prod, past production; Iden, identified resources; Undis, undiscovered resources. 


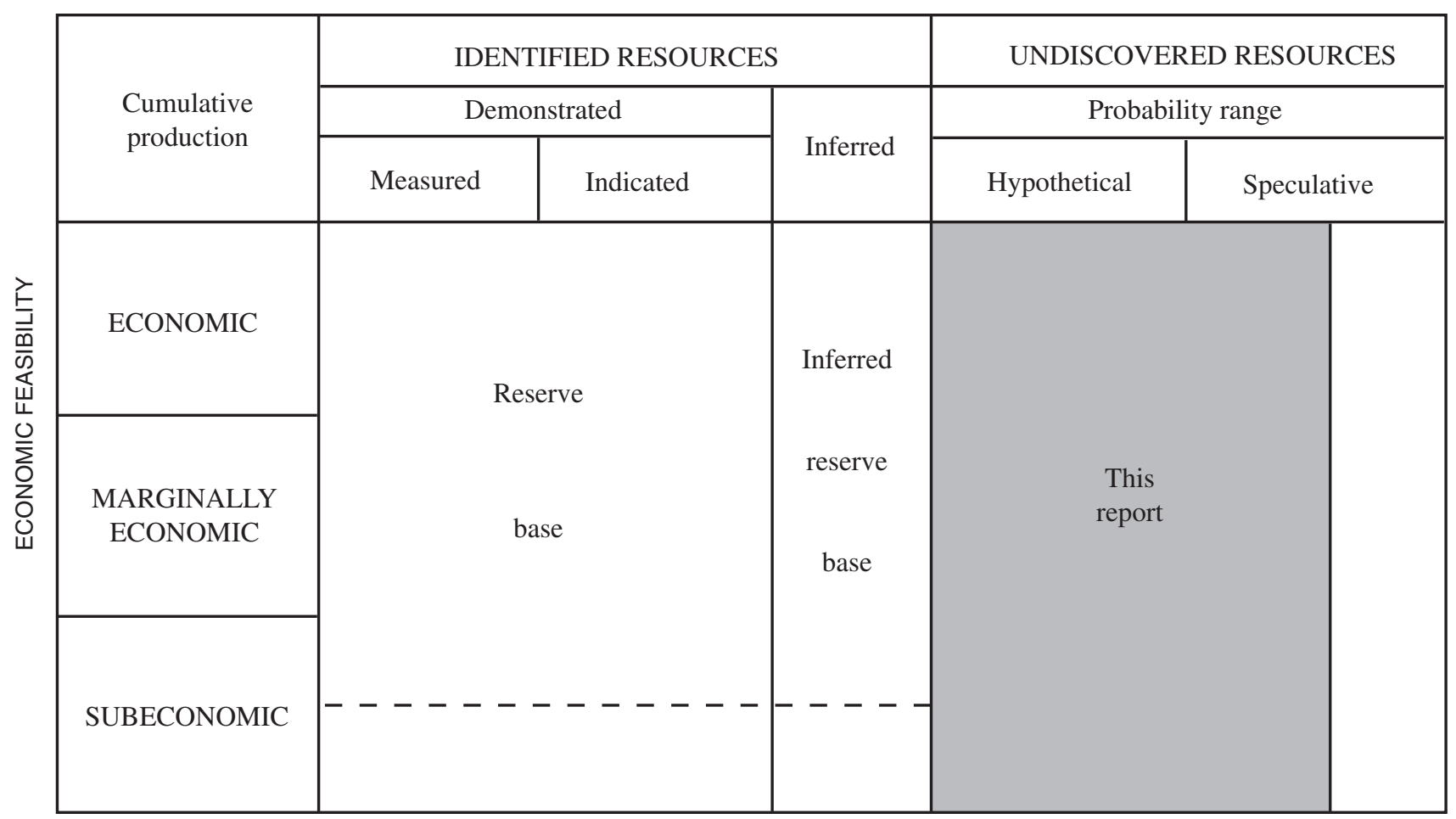

GEOLOGIC CERTAINTY

Figure 2. Mineral resource classification used in this report (modified from McKelvey, 1972; U.S. Bureau of Mines and U.S. Geological Survey, 1980; U.S. Geological Survey, 1998). The degree of geologic certainty decreases to the right; the degree of economic feasibility decreases downward.

production is not part of identified resources and thus is not indicated in figure 2 . The undiscovered resources estimated in this report include the hypothetical category and part of the speculative category. Identified resources include the demonstrated and inferred categories.

\section{TERMINOLOGY}

The terminology used in this report is intended to represent standard definitions and usage by the minerals industry and the resource assessment community (U.S. Bureau of Mines and U.S. Geological Survey, 1980; American Geological Institute, 1997). No attempt has been made to include a detailed listing of all the definitions; rather, those definitions that are essential to the proper understanding of this report are presented. Some of the definitions are intended to be generally explanatory rather than strictly technical. A few of the definitions are specific to this report.

Mineral deposit. A mineral concentration of sufficient size and grade richness that it might, under the most favorable of circumstances, be considered to have potential for economic development.

Undiscovered mineral deposit. A mineral deposit believed to exist $1 \mathrm{~km}$ or less below the surface of the ground, or an incompletely explored mineral occurrence or prospect that could have sufficient size and grade to be classed as a deposit.

Significant mineral deposit. A mineral deposit known or believed to contain at least $2 \mathrm{t}$ of gold, or $85 \mathrm{t}$ of silver, or 50,000 $\mathrm{t}$ of copper, or 35,000 $\mathrm{t}$ of lead, or 50,000 t of zinc (Singer, 1995).

Descriptive mineral deposit model. A set of data in a convenient form that describes a group of mineral deposits having similar characteristics.

Grade and tonnage model. Frequency distributions of the grade and size of well-explored individual mineral deposits.

Permissive tract. A geographic area delineated such that the probability of deposits of the type delineated occurring outside the boundary is negligible.

Resource. A mineral concentration of sufficient size and grade and in such form and amount that economic extrac- 
tion of a commodity from the concentration is currently or potentially feasible.

Identified resources. Resources whose location, grade, quality, and quantity are known or are estimatable from specific geologic evidence.

Demonstrated resource. The sum of measured plus indicated resources.

Measured resource. Quantity computed from dimensions revealed in outcrops, trenches, workings, or drill holes; grade and (or) quality computed from the results of detailed sampling. The sites for inspection, sampling, and measurement are spaced so closely and the geologic character is so well defined that size, shape, depth, and mineral content of the resource are well established.

Indicated resource. Quantity and grade and (or) quality computed from information similar to that used for measured resources. However, the sites for inspection, sampling, and measurement are farther apart or are otherwise less adequately spaced. The degree of assurance, although lower than that for measured resources, is high enough to assume continuity between points of observation.

Reserve base. That part of an identified resource that meets specified minimum physical and chemical criteria related to current mining and production practices. The reserve base is the in-place demonstrated (measured plus indicated) resource from which reserves are estimated and includes those resources that are currently economic (reserves), those that are marginally economic, and some of those that are currently subeconomic.

Reserves. That part of the reserve base that can be economically extracted or produced at the time of determination.

Inferred resource. Estimates of resource that are based on an assumed continuity beyond measured and (or) indicated resources for which there is geologic evidence. Inferred resources may or may not be supported by samples or measurements.

Inferred reserve base. The postulated extension of the reserve base. The inferred reserve base is an estimate based on an assumed continuity beyond identified resources for which there is geologic evidence. The inferred reserve base is the in-place part of an identified resource from which inferred reserves are estimated.

Inferred reserves. The postulated extension of reserves. Inferred reserves are estimates that are based on an assumed continuity beyond measured and (or) indicated reserves for which there is geologic evidence.
Undiscovered resources. Resources in undiscovered mineral deposits whose existence is postulated on the basis of indirect geologic evidence.

Hypothetical resources. Undiscovered resources in known types of mineral deposits postulated to exist in favorable geologic settings where other deposits of the same types have been mined.

Speculative resources. Undiscovered resources that may occur either in known types of deposits in favorable geologic settings where mineral discoveries have not been made or in types of deposits as yet unrecognized for their economic potential.

Cumulative past production. The total amount of all past production.

Discovered resources. The total amount of identified resources and cumulative past production.

\section{DATA BASE}

The National Mineral Resource Assessment is based mainly on data collected and reviewed from 1993 to 1998. The data were either published, commercially available, or from unpublished USGS studies. Data sources included the following:

- Published and unpublished USGS geologic, geochemical, geophysical, mineral deposit, and mineral-occurrence data at scales of 1:500,000 and $1: 1,000,000$ that were used to define the boundaries of tracts of land permissive for the occurrence of undiscovered mineral deposits.

- USGS data on mineral deposit models that included descriptive and grade and tonnage models.

- Data from the USGS and the former U.S. Bureau of Mines on past production.

- Production and resource data from Securities and Exchange Commission 10K forms.

- Geologic, geochemical, geophysical, mineral deposit, and mineral-occurrence data maintained by State geological surveys.

- Published articles in the academic literature.

- Periodicals and newsletters that serve the mining industry.

The data base of the tracts that were used to generate the resource estimates obtained in the National Mineral Resource Assessment is stored on a Compact Disc-Read Only Memory (CD-ROM), which is included in a pocket at the end of this report. The CD-ROM also contains this circular and a browser that can be used to examine the tracts by region and by major deposit model type and the significant mineral deposits that occur in the tracts. The data base consists of the following:

- Estimates of the tonnages and amounts of contained metal in undiscovered deposits, 
- A table that lists the mineral deposit model types used in the National Mineral Resource Assessment,

- A table that lists the tonnages and amounts of contained metal in the significant mineral deposits in the United States,

- The rationale that was used to assess each of the tracts in the National Mineral Resource Assessment, and

- A list of references for each tract in the National Mineral Resource Assessment.

The browser is a map-based, stand-alone Windows application that can be installed from the CD-ROM. The browser allows a user to click on a tract for a selected mineral deposit model type and to display either the tabular data associated with the tract or the rationale that was used to assess the tract. The rationale contains hypertext links to the tonnage and amounts of contained metal in undiscovered deposits, the mineral deposit model type used to assess the particular tract, and the significant mineral deposits associated with the tract. A user can also choose to display the assessment regions, mining districts, and the significant mineral deposits, as well as several standard thematic layers such as political boundaries, cities, airports, rivers, and color-shaded relief.

\section{AREAS OF STUDY}

The undiscovered resources of gold, silver, copper, lead, and zinc in the United States were evaluated by interpreting the known geology of the 19 assessment regions shown in figure 3 . The regions were constructed to provide broad geologic groupings of the Nation's mineral-producing regions. The regions are named for structural or geographic features within their boundaries.

\section{METHOD OF ASSESSMENT}

The method used to estimate the quantity and quality of undiscovered deposits of gold, silver, copper, lead, and zinc was based on the three-part form of quantitative assessment described by Singer (1993). In three-part assessments, areas are delineated according to the types of deposits permitted by the geology, the amount of metal in typical deposits is estimated by using grade and tonnage models, and the number of undiscovered deposits of each type is estimated by using a variety of subjective methods. Estimates of the number of undiscovered deposits are consistent in that the geologic settings of the delineated areas are consistent with the geologic settings for the descriptive models, as well as for the identified resources in the area and the deposits that constitute the grade and tonnage models. Every effort is made to incorporate the available information in the estimates, and the uncertainty is explicitly represented. The three-part form of quantitative assessment has been applied by the USGS since 1975 .

\section{UNDISCOVERED DEPOSITS}

The national assessment was conducted by 19 regional assessment teams of scientists from the USGS. Each team comprised geologists, geochemists, geophysicists, and resource analysts. To begin an assessment, existing data for large (Alaska) and multi-State assessment regions were compiled into maps at scales of 1:500,000 and 1:1,000,000. For each region, a team reviewed the geology and decided upon the appropriate mineral deposit models to be used in making the assessment. On the basis of all the available information, permissive tracts then were delineated for each deposit model type such that the probability was negligible that undiscovered deposits for a particular deposit model type would occur outside the tract boundary.

Maps showing the geology and the locations and types of mineral deposits and occurrences were used in outlining these permissive tracts. Geophysical and geochemical maps also were useful, as well as knowledge of the exploration history of the areas.

Estimates of the undiscovered resources were made to a depth of $1 \mathrm{~km}$ beneath the surface. If an area of otherwise permissive rock was covered by more than $1 \mathrm{~km}$ of rock known or was inferred to be barren, then the area was excluded from the tract. The somewhat arbitrary depth of 1 $\mathrm{km}$ was chosen as the limit below which the existence of undiscovered deposits would not be considered because of difficulties in acquiring and (or) extrapolating geologic, geochemical, and geophysical data to greater depths. Because some mineral deposits have vertical extents of more than $1 \mathrm{~km}$, the rule was adopted such that if any part of a deposit was judged to be within $1 \mathrm{~km}$ of the surface, then the whole deposit was counted. This rationale is consistent with mining practice. Although direct mineral exploration is seldom conducted below $1 \mathrm{~km}$, deposits may be explored and developed up to $3 \mathrm{~km}$ deep once they have been discovered at lesser depths.

The regional assessment teams reviewed grade and tonnage data for all identified resources in a tract, then decided whether worldwide models were applicable, and modified the models if necessary. In most cases, the models used were those described in Cox and Singer (1986) and Bliss (1992). In cases for which it was not possible to use these worldwide models, local models were used. The undiscovered deposits estimated to exist in the tract were treated as if they would be similar in grade and tonnage to the deposits in the deposit model (either accepted or modified).

Where available information warranted making quantitative estimates, the teams then estimated the number of undiscovered deposits of each deposit model type that might exist in each permissive tract. These estimates were made by subjective interpretation and extrapolation of available earth science information. The number of undiscovered deposits was estimated at different levels of 


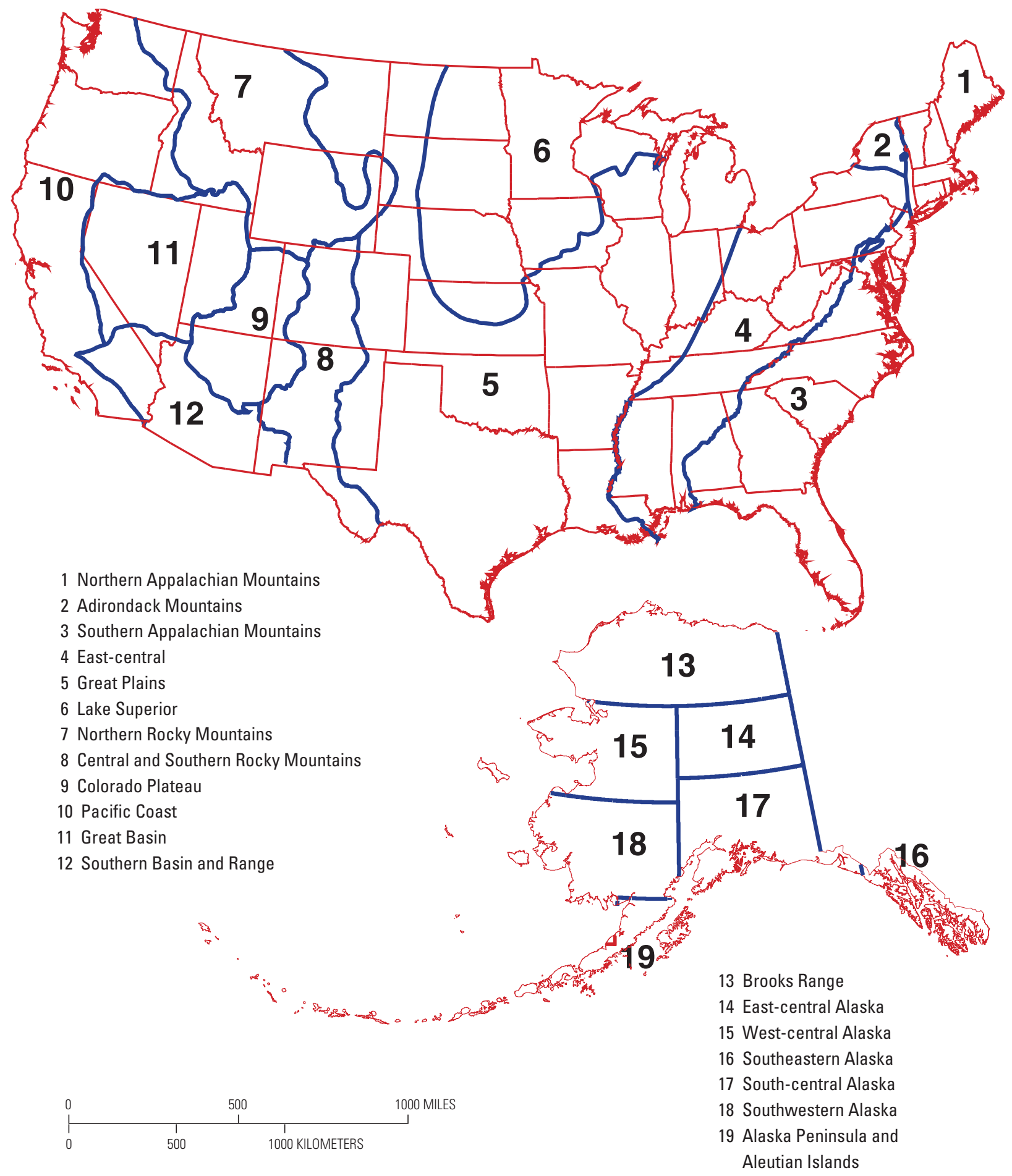

Figure 3. Geographic regions assessed in this report. Heavy lines, region boundaries; light lines, State boundaries. 
certainty. For example, on the basis of all the available information, a team might estimate that there was a 90 -percent chance or better that one or more undiscovered deposits existed; a 50-percent chance or better that three or more existed; and a 10-percent chance or better that five or more existed. Commonly, estimators made estimates for five levels of certainty-90th, 50th, 10th, 5th, and 1st percentiles.

The estimates were made by scientists who had detailed knowledge of an area and (or) the selected deposit model. The teams used a variety of methods to arrive at a consensus. The most common method was simply to continue their discussion until general agreement was reached. Decision-aiding tools, such as deposit spatial density models and assumptions about the extent of exploration, also were used to guide the final estimates (Singer, 1993). The result of the estimation process was a probability distribution of the number of undiscovered deposits. In cases where the grade and tonnage model was based on data for a mineral district rather than for individual deposits, the result was a probability distribution of the number of undiscovered districts.

\section{PROBABILITY OF NO DEPOSITS}

In some cases, it was necessary to estimate the probability of no deposits. This was done primarily when estimates of the numbers of undiscovered deposits at all levels of certainty were small and the estimators wished to further constrain the probability density estimates.

\section{MONTE CARLO SIMULATION}

A Monte Carlo simulation computer program was used to combine the probability distribution of the number of undiscovered deposits with the grade and tonnage data sets associated with each deposit model to obtain the probability distribution for undiscovered metal in each tract (Root, Menzie, and Scott, 1992; Root, Scott, and Selner, 1997). Estimates of the undiscovered metal in each tract were represented as a range of values corresponding to probabilities of occurrence to express the uncertainty inherent in the assessment of unknown quantities. The input variables - the number of undiscovered deposits and the tonnages and grades of the deposits in the deposit models-were expressed as cumulative probability distributions of uncertain values. The resulting cumulative probability distributions represented the estimated quantity of gold, silver, copper, lead, and zinc. From these distributions, various fractiles, including the low $\left(\mathrm{F}_{90}\right)$, the high $\left(\mathrm{F}_{10}\right)$, and the mean estimates, were obtained.

Unrealistically large values for grades and tonnages of undiscovered deposits can result from the highly skewed cumulative probability distributions, which are often characteristic of deposit data. To avoid such unrealistic values, piecewise linear approximations of the tonnage and grades of metals in the deposit data were used in the simulations. To preserve the dependencies of grades in the deposit data, the deposits within each model were grouped into suites according to the metals they contained, and each suite was sampled proportionally to its frequency of occurrence for that deposit model. Also, the tonnages of the deposits in each suite had different distributions depending upon the suite of metals present.

\section{AGGREGATION AND DEPENDENCY}

To arrive at the estimated quantity of undiscovered deposits of gold, silver, copper, lead, and zinc for large areas, such as geographic regions or the Nation as a whole, distributions estimated for individual tracts were progressively aggregated, with geologic dependency incorporated at each level of aggregation. To aggregate tracts within regions, tracts assessed by the same team of estimators were assumed to be perfectly correlated, whereas tracts assessed by different teams were assumed to be uncorrelated. In aggregating regions to obtain a national total, regions were assumed to be statistically independent.

\section{SIGNIFICANT DEPOSITS}

As a part of the 1998 National Mineral Resource Assessment, a data base was compiled for the largest identified resources of gold, silver, copper, lead, and zinc in the United States (Long and others, 1998). The resources in this data base accounted for about 99 percent of domestic production of these metals and probably a similar share of identified resources.

Production data for deposits in the data base were stated in terms of metals recovered. Generally, between 40 and 97 percent of the metal originally contained in the ores was recovered, depending on the efficiency of the extractive processes used and the quality of labor and management. The data included those situations in which the initial mining operations recovered so little of the contained metal that the resulting waste heaps were reprocessed later. Resource data for deposits in the data base were stated in terms of metals contained in remaining material. The sum of the past production and the remaining (identified) resources was the total discovered resources reported herein.

\section{RESULTS OF THE ASSESSMENT}

A total of 55 major deposit model and submodel types were used to delineate 447 permissive tracts for the 1998 assessment. Quantitative assessments were made for 305 of these tracts (CD-ROM, in pocket). The 30 major deposit model types used in the quantitative assessments are listed in table 2. 
Table 2. Deposit models and their descriptions and major metals used in quantitative assessment of 305 of the 447 permissive tracts delineated in the 1998 National Mineral Resource Assessment.

[Deposit models based on Cox and Singer (1986) and Bliss (1992). The plutonic porphyry gold deposit model is based on Hollister (1992). For grade and tonnage data for specific models, refer to Root, Scott, and Selner (1997)]

\begin{tabular}{|c|c|c|}
\hline Deposit model & Description & Major metals \\
\hline $\begin{array}{l}\text { Alaskan platinum group elements } \\
\text { (PGE) ------ }\end{array}$ & $\begin{array}{l}\text { Crosscutting ultramafic to felsic intrusive rocks with approximately concentric zoning of rock types that contain } \\
\text { chromite, platinum, and titanium-vanadium-magnetite. }\end{array}$ & $\mathrm{Cr}, \mathrm{PGE}, \mathrm{Ti}, \mathrm{V}, \mathrm{Cu}, \mathrm{N}$ \\
\hline Alkaline gold-tellurium ----------- & Veins or breccias associated with alkalic igneous rocks that contain gold \pm gold tellurides \pm vanadian micas. & $\mathrm{Au}, \mathrm{Te}$ \\
\hline Gold skarn-------------------------- & $\begin{array}{l}\text { Gold in skarns near intrusive igneous contacts. Includes copper, zinc, lead, and iron skarns with gold as a major } \\
\text { commodity. }\end{array}$ & $\mathrm{Au}$ \\
\hline Basaltic copper --------------------- & Disseminated native copper and copper sulfides in the upper parts of thick sequences of subaerial basalt. & $\mathrm{Cu}$ \\
\hline Besshi massive sulfide------------- & $\begin{array}{l}\text { Thin, sheetlike bodies of massive to well-laminated pyrite, pyrrhotite, and chalcopyrite within thinly laminated } \\
\text { clastic sediments associated with basalt flows and tuffs. }\end{array}$ & $\mathrm{Cu}, \mathrm{Ag}, \mathrm{Au}, \mathrm{Zn}$ \\
\hline Comstock epithermal vein -------- & $\begin{array}{l}\text { Gold, electrum, silver sulfosalts, and argentite in vuggy quartz-adularia veins hosted by felsic to intermediate vol- } \\
\text { canic rocks that overlie predominantly clastic sedimentary rocks and their metamorphic equivalents. }\end{array}$ & $\mathrm{Au}, \mathrm{Ag}$ \\
\hline Creede epithermal vein ------------ & $\begin{array}{l}\text { Galena, sphalerite, chalcopyrite, sulfosalts, } \pm \text { tellurides, } \pm \text { gold in quartz-carbonate veins hosted by felsic to inter- } \\
\text { mediate volcanics. }\end{array}$ & $\mathrm{Cu}, \mathrm{Pb}, \mathrm{Zn}, \mathrm{Ag}, \mathrm{Au}$ \\
\hline Copper skarn---------------------- & Chalcopyrite in calc-silicate metasomatic rocks near contacts with weakly mineralized igneous intrusives. & $\mathrm{Cu}, \mathrm{Ag}, \mathrm{Au}$ \\
\hline Distal disseminated silver-gold--- & $\begin{array}{l}\text { Disseminated silver and gold mainly in sedimentary rocks distal to porphyry copper, skarns, and polymetallic } \\
\text { veins. }\end{array}$ & $\mathrm{Au}, \mathrm{Ag}$ \\
\hline Homestake, stratiform gold ------- & $\begin{array}{l}\text { Gold in massive persistent quartz veins mainly in shear zones in regionally metamorphosed Archean and Protero- } \\
\text { zoic volcanic rocks and volcanic sediments. }\end{array}$ & $\mathrm{Au}, \mathrm{Ag}$ \\
\hline Hot spring gold-silver ------------ & Fine-grained silica and quartz in silicified breccia with gold, pyrite, and antimony and arsenic sulfides. & $\mathrm{Au}, \mathrm{Ag}$ \\
\hline Kuroko massive sulfide------------ & Copper- and zinc-bearing massive sulfide deposits in marine volcanic rocks of intermediate to felsic composition. & $\mathrm{Cu}, \mathrm{Pb}, \mathrm{Zn}, \mathrm{Au}, \mathrm{Ag}$ \\
\hline Low-sulfide gold-quartz vein ----- & $\begin{array}{l}\text { Gold in massive persistent quartz veins mainly in shear zones in regionally metamorphosed volcanic rocks and vol- } \\
\text { canic sediments. }\end{array}$ & $\mathrm{Au}, \mathrm{Ag}$ \\
\hline $\begin{array}{l}\text { Mississippi Valley/southeast Mis- } \\
\text { souri lead-zinc -------------- }\end{array}$ & $\begin{array}{l}\text { Stratabound, carbonate-hosted deposits of galena, sphalerite, and chalcopyrite in rocks having primary and second- } \\
\text { ary porosity, commonly related to reefs on paleotopographic highs. }\end{array}$ & $\mathrm{Zn}, \mathrm{Pb}, \mathrm{Ag}$ \\
\hline $\begin{array}{l}\text { Mississippi Valley/Appalachian } \\
\text { zinc------ }\end{array}$ & $\begin{array}{l}\text { Stratabound deposits of sphalerite and minor galena in primary and secondary voids in favorable beds or horizons } \\
\text { in thick platform dolostone and limestone. }\end{array}$ & $\mathrm{Zn}, \mathrm{Pb}, \mathrm{Ag}$ \\
\hline Native copper ------------------ & Native copper filling vesicles, breccias, and fractures in subaerial basalt. & $\mathrm{Cu}$ \\
\hline 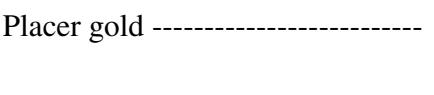 & $\begin{array}{l}\text { Elemental gold and platinum-group alloys in grains and (rarely) nuggets in gravel, sand, silt, and clay and their } \\
\text { consolidated equivalents, in alluvial, beach, eolian, and (rarely) glacial deposits. }\end{array}$ & $\mathrm{Au}, \mathrm{Ag}$ \\
\hline Plutonic porphyr & Gold in stockwork veinlets in hydrothermally altered granodiorite and quartz monzonite porphyry. & $\mathrm{Au}$ \\
\hline
\end{tabular}

porphyry gold - 


\begin{tabular}{|c|c|c|}
\hline Deposit model & Description & Major metals \\
\hline Polymetallic replacement --------- & $\begin{array}{l}\text { Hydrothermal, epigenetic, silver, lead, zinc, and copper minerals in massive lenses, pipes, and veins in limestone, } \\
\text { dolomite, or other soluble rock near igneous intrusive contacts. }\end{array}$ & $\mathrm{Pb}, \mathrm{Zn}, \mathrm{Cu}, \mathrm{Ag}, \mathrm{Au}$ \\
\hline Polymetallic vein------------------- & $\begin{array}{l}\text { Quartz-carbonate veins with gold and silver associated with base metal sulfides related to hypabyssal intrusions in } \\
\text { sedimentary and metamorphic terranes. }\end{array}$ & $\mathrm{Ag}, \mathrm{Au}, \mathrm{Pb}, \mathrm{Zn}, \mathrm{Cu}$ \\
\hline Porphyry copper-------------------- & $\begin{array}{l}\text { Generalized model includes various subtypes, all of which contain chalcopyrite in stockwork veinlets in hydrother- } \\
\text { mally altered porphyry and adjacent country rock. }\end{array}$ & $\mathrm{Cu}, \mathrm{Ag}, \mathrm{Au}, \mathrm{Mo}$ \\
\hline Porphyry copper, skarn-related--- & $\begin{array}{l}\text { Chalcopyrite in stockwork veinlets in hydrothermally altered and mineralized porphyry and in calc-silicate contact } \\
\text { metasomatic rocks with extensive retrograde alteration. }\end{array}$ & $\mathrm{Cu}, \mathrm{Ag}, \mathrm{Au}, \mathrm{Mo}$ \\
\hline Porphyry copper-gold ------------- & $\begin{array}{l}\text { Stockwork veinlets of chalcopyrite, bornite, and magnetite in porphyritic intrusions and coeval volcanic rocks. } \\
\text { Ratio of gold (parts per million) to molybdenum (percent) is greater than } 30 .\end{array}$ & $\mathrm{Cu}, \mathrm{Au}, \mathrm{Ag}, \mathrm{Mo}$ \\
\hline Porphyry copper-molybdenum--- & $\begin{array}{l}\text { Stockwork veinlets of quartz, chalcopyrite, and molybdenite in or near a porphyritic intrusion. Ratio of gold (in } \\
\text { parts per million) to molybdenum (percent) is less than } 3 \text {. }\end{array}$ & $\mathrm{Cu}, \mathrm{Mo}, \mathrm{Au}, \mathrm{Ag}$ \\
\hline Quartz-adularia epithermal vein - & $\begin{array}{l}\text { Gold, electrum, silver sulfosalts, and argentite in vuggy quartz-adularia veins hosted by felsic-to-intermediate vol- } \\
\text { canic rocks that overlie unspecified basement. }\end{array}$ & $\mathrm{Au}, \mathrm{Ag}, \mathrm{Cu}, \mathrm{Zn}, \mathrm{Pb}$ \\
\hline Sediment-hosted gold ------------- & $\begin{array}{l}\text { Very fine grained gold, pyrite, and arsenic-antimony sulfides disseminated in carbonaceous calcareous and sili- } \\
\text { ceous sedimentary rocks and associated jasperoids. }\end{array}$ & $\mathrm{Au}, \mathrm{Ag}$ \\
\hline Sediment-hosted copper----------- & Stratabound, disseminated copper sulfides in reduced beds of red-bed sequences. & $\mathrm{Cu}, \mathrm{Ag}, \mathrm{Co}$ \\
\hline Sedimentary exhalative zinc-lead & $\begin{array}{l}\text { Stratiform basinal accumulations of sulfides and barite interbedded with euxinic marine sediments form sheet- or } \\
\text { lenslike ore bodies tens of meters thick, distributed through a stratigraphic interval of more than } 1,000 \mathrm{~m} \text {. }\end{array}$ & $\mathrm{Zn}, \mathrm{Pb}, \mathrm{Ag}$ \\
\hline $\begin{array}{l}\text { Synorogenic-synvolcanic } \\
\text { nickel-copper ----------------- }\end{array}$ & Massive lenses, matrix and disseminated sulfide in small to medium-sized gabbroic intrusions in greenstone belts. & $\mathrm{Ni}, \mathrm{Cu}$ \\
\hline Zinc-lead skarn ------------------- & Sphalerite and galena in calc-silicate rocks near igneous intrusive contacts. & $\mathrm{Zn}, \mathrm{Pb}, \mathrm{Ag}, \mathrm{Au}, \mathrm{Cu}$ \\
\hline
\end{tabular}


Examples of submodels that were used include a British Columbia/Alaska porphyry copper submodel, a North America porphyry copper submodel, a modified gold-skarn deposit model for the Western United States, a reduced-facies submodel for the sediment-hosted copper deposit model, a Precambrian-only submodel for the kuroko massive sulfide deposit model, and an Archean submodel for the low-sulfide gold-quartz vein deposit model. In one case, a single deposit, Chicken Mountain in Alaska, was the sole representative of a plutonic porphyry gold submodel. Submodels were constructed and used when the teams' detailed knowledge of the local geology suggested that the general models did not adequately represent identified mineral deposits in a permissive tract for which undiscovered resources were being estimated.

It is easiest to discuss the results of the 1998 National Mineral Resource Assessment one metal at a time.

\section{GOLD}

The estimate of the amount of gold in undiscovered mineral deposits in the United States ranged from 13,000 $\mathrm{t}$ at a 90 -percent probability to $22,000 \mathrm{t}$ at a 10 -percent probability. The mean estimate of gold in undiscovered deposits was 18,000 t. Estimated amounts of gold are listed by region in table 3 and shown by major deposit type in figure 4 .

Nearly one-quarter of the gold was estimated to be contained in undiscovered porphyry copper deposits. Other major deposit types were hot spring gold, epithermal vein, plutonic porphyry gold, sediment-hosted gold, Au-Ag-Te veins, and low-sulfide gold-quartz vein deposits. The identified gold resource was estimated to be $15,000 \mathrm{t}$. Past production was estimated to be $12,000 \mathrm{t}$. The total discovered gold resource in the United States was estimated to be $27,000 \mathrm{t}$.

\section{SILVER}

The estimate of the amount of silver in undiscovered mineral deposits ranged from $290,000 \mathrm{t}$ at a 90 -percent probability to $660,000 \mathrm{t}$ at a 10 -percent probability. The mean estimate of silver in undiscovered deposits was 460,000 t. Estimated amounts of silver are listed by region in table 3 and shown by major type in figure 5 .

Nearly one-half of the silver was thought to be contained in undiscovered sediment-hosted copper and epithermal vein deposits. Other major deposit types were polymetallic replacement, sedimentary exhalative, porphyry copper, and volcanogenic massive sulfide deposits. The identified silver resource was estimated to be 160,000 t. Past production was estimated to be $170,000 \mathrm{t}$. The total discovered silver resource in the United States was estimated to be $330,000 \mathrm{t}$.

\section{COPPER}

The amount of copper in undiscovered mineral deposits was estimated to range from $170,000 \mathrm{kt}$ at a 90 -percent probability to $440,000 \mathrm{kt}$ at a 10 -percent probability. The mean estimate of copper in undiscovered deposits was $290,000 \mathrm{kt}$. Estimated amounts of copper are listed by region in table 3 and shown by major type in figure 6 .

More than two-thirds of the copper was thought to be contained in undiscovered porphyry copper deposits. Other major deposit types were sediment-hosted copper and volcanogenic massive sulfide deposits. The identified copper resource was estimated to be $260,000 \mathrm{kt}$. Past production was estimated to be $91,000 \mathrm{kt}$. The total discovered copper resource in the United States was estimated to be $350,000 \mathrm{kt}$.

\section{LEAD}

The estimate of the amount of lead in undiscovered mineral deposits ranged from 47,000 kt at a 90-percent probability to $130,000 \mathrm{kt}$ at a 10 -percent probability. The mean estimate of lead in undiscovered deposits was $85,000 \mathrm{kt}$. Estimated amounts of lead are listed by region in table 3 and shown by major type in figure 7 .

Nearly one-half of the lead was thought to be contained in undiscovered sedimentary exhalative deposits. Other major deposit types were Mississippi Valley and polymetallic replacement deposit types. The identified lead resource was estimated to be 51,000 kt. Past production was estimated to be $41,000 \mathrm{kt}$. The total discovered lead resource in the United States was estimated to be $92,000 \mathrm{kt}$.

\section{ZINC}

The estimate of the amount of zinc in undiscovered deposits ranged from $130,000 \mathrm{kt}$ at a 90 -percent probability to $290,000 \mathrm{kt}$ at a 10 -percent probability. The mean estimate of zinc in undiscovered deposits was 210,000 kt. Estimated amounts of zinc are listed by region in table 3 and shown by major type in figure 8 .

Nearly 40 percent of the zinc was thought to be contained in undiscovered Mississippi Valley-type deposits. Other major deposit types were sedimentary exhalative, volcanogenic massive sulfide, and polymetallic replacement deposit types. The identified zinc resource was estimated to be 55,000 kt. Past production was estimated at 44,000 kt. The total discovered zinc resource in the United States was estimated to be $99,000 \mathrm{kt}$. 
Table 3. Estimates of contained metal in undiscovered deposits in the United States.

[Mean value totals may not be equal to the sums of the component means given elsewhere because numbers have been independently rounded. Fractile values $\left(\mathrm{F}_{90}\right.$, $\left.\mathrm{F}_{10}\right)$ are derived from the cumulative probability distributions of the contained metals for each area or of the total area and are nonadditive. $\mathrm{F}_{90}$ represents a 9-in-10 chance, and $\mathrm{F}_{10}$ represents a 1-in- 10 chance, of the occurrence of at least the amount tabulated. NM, no metal]

\begin{tabular}{|c|c|c|c|c|c|c|c|c|c|c|c|c|c|c|c|}
\hline \multirow{2}{*}{ Assessment region } & \multicolumn{3}{|c|}{$\begin{array}{c}\text { Gold } \\
\text { (tons) }\end{array}$} & \multicolumn{3}{|c|}{$\begin{array}{l}\text { Silver } \\
\text { (tons) }\end{array}$} & \multicolumn{3}{|c|}{$\begin{array}{c}\text { Copper } \\
\text { (kilotons) }\end{array}$} & \multicolumn{3}{|c|}{$\begin{array}{c}\text { Lead } \\
\text { (kilotons) }\end{array}$} & \multicolumn{3}{|c|}{$\begin{array}{c}\text { Zinc } \\
\text { (kilotons) }\end{array}$} \\
\hline & $\mathrm{F}_{90}$ & $\mathrm{~F}_{10}$ & Mean & $\mathrm{F}_{90}$ & $\mathrm{~F}_{10}$ & Mean & $\mathrm{F}_{90}$ & $\mathrm{~F}_{10}$ & Mean & $\mathrm{F}_{90}$ & $\mathrm{~F}_{10}$ & Mean & $\mathrm{F}_{90}$ & $\mathrm{~F}_{10}$ & Mean \\
\hline \multicolumn{16}{|l|}{ Alaska } \\
\hline $\begin{array}{l}\text { Alaska Peninsula and } \\
\text { Aleutian Islands--------- }\end{array}$ & 110 & 1,400 & 680 & 1,900 & 26,000 & 12,000 & 2,000 & 20,000 & 10,000 & 60 & 1,100 & 500 & 30 & 820 & 360 \\
\hline Brooks Range ---------- & 0 & 140 & 54 & 660 & 34,000 & 14,000 & 32 & 1,400 & 580 & 580 & 23,000 & 9,500 & 1,600 & 39,000 & 17,000 \\
\hline East-central -------------- & 120 & 1,300 & 660 & 0 & 2,000 & 710 & 58 & 4,500 & 1,800 & NM & NM & NM & NM & NM & NM \\
\hline South-central ------------ & 320 & 3,100 & 1,700 & 1,200 & 2,200 & 10,000 & 3,600 & 36,000 & 19,000 & 5 & 1,500 & 580 & 130 & 7,700 & 3,100 \\
\hline Southeastern----------- & 0 & 280 & 100 & 78 & 11,000 & 3,900 & 10 & 1,800 & 5,700 & 8 & 1,200 & 510 & 8 & 2,300 & 1,000 \\
\hline Southwestern ------------ & 360 & 2,000 & 1,100 & 14 & 14,000 & 5,200 & 120 & 6,000 & 2,500 & 1 & 9,900 & 3,600 & 10 & 20,000 & 6,500 \\
\hline West-central ------------- & 0 & 37 & 18 & 0 & 1 & 2 & NM & NM & NM & NM & NM & NM & NM & NM & NM \\
\hline Statewide ---------------- & 280 & 700 & 480 & 1,500 & 56,000 & 24,000 & 2 & 860 & 310 & 2,100 & 50,000 & 22,000 & 5,100 & 86,000 & 41,000 \\
\hline TOTAL, Alaska ------------- & 3,400 & 6,200 & 4,800 & 36,000 & 110,000 & 72,000 & 23,000 & 57,000 & 39,000 & 13,000 & 69,000 & 38,000 & 30,000 & 110,000 & 69,000 \\
\hline \multicolumn{16}{|l|}{$\begin{array}{l}\text { United States exclusive of } \\
\text { Alaska }\end{array}$} \\
\hline Adirondack Mountains ---- & NM & NM & NM & NM & NM & NM & NM & NM & NM & NM & NM & NM & 0 & 0 & 640 \\
\hline $\begin{array}{c}\text { Central and Southern Rocky } \\
\text { Mountains--------- }\end{array}$ & 180 & 2,700 & 1,200 & 1,200 & 40,000 & 17,000 & 1,300 & 14,000 & 6,700 & 97 & 5,600 & 2,300 & 85 & 6,800 & 2,700 \\
\hline Colorado Plateau --------- & NM & NM & NM & 0 & 1 & 0 & 0 & 350 & 100 & NM & NM & NM & NM & NM & NM \\
\hline East-central-------------- & NM & NM & NM & 110 & 15,000 & 5,400 & NM & NM & NM & 900 & 14,000 & 7,100 & 7,800 & 104,000 & 52,000 \\
\hline Great Basin ------------- & 1,600 & 6,400 & 3,800 & 31,000 & 170,000 & 92,000 & 3,700 & 86,000 & 39,000 & 1,800 & 14,000 & 7,300 & 2,400 & 17,000 & 9,200 \\
\hline Great Plains ----------- & NM & NM & NM & 0 & 47,000 & 19,000 & 180 & 42,000 & 17,000 & 29 & 19,000 & 7,200 & 1,000 & 37,000 & 16,000 \\
\hline Lake Superior----------- & 260 & 1,700 & 880 & 3,800 & 170,000 & 61,000 & 6,800 & 70,000 & 35,000 & 130 & 1,600 & 900 & 3,300 & 31,000 & 14,000 \\
\hline Northern Appalachians --- & 32 & 460 & 220 & 2,400 & 35,000 & 16,000 & 1,300 & 15,000 & 8,100 & 500 & 20,000 & 7,900 & 2,600 & 38,000 & 17,000 \\
\hline $\begin{array}{l}\text { Northern Rocky } \\
\text { Mountains ------------ }\end{array}$ & 220 & 4,100 & 1,900 & 11,000 & 130,000 & 65,000 & 4,900 & 52,000 & 24,000 & 120 & 18,000 & 6,700 & 210 & 28,000 & 11,000 \\
\hline Pacific Coast ---------- & 1,000 & 3,300 & 2,100 & 11,000 & 66,000 & 33,000 & 2,400 & 19,000 & 9,800 & 1 & 710 & 340 & 31 & 3,800 & 1,700 \\
\hline Southern Appalachians --- & 350 & 1,900 & 1,100 & 2,500 & 29,000 & 16,000 & 1,900 & 20,000 & 9,600 & 140 & 4,300 & 1,800 & 960 & 15,000 & 7,300 \\
\hline Southern Basin and Range & 770 & 3,200 & 1,800 & 25,000 & 110,000 & 64,000 & 18,000 & 220,000 & 110,000 & 1,100 & 12,000 & 5,800 & 1,300 & 14,000 & 6,800 \\
\hline $\begin{array}{l}\text { TOTAL, United States includ- } \\
\text { ing Alaska-- }\end{array}$ & 13,000 & 22,000 & 18,000 & 290,000 & 660,000 & 460,000 & 170,000 & 440,000 & 290,000 & 47,000 & 130,000 & 85,000 & 130,000 & 290,000 & 210,000 \\
\hline
\end{tabular}




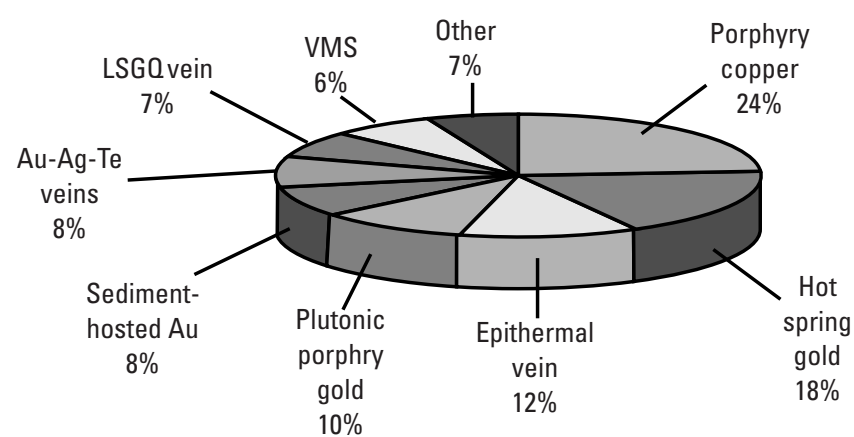

Figure 4. Gold in undiscovered mineral deposits, by major deposit type. LSGQ vein, low-sulfide gold-quartz vein; VMS, volcanogenic massive sulfide (includes Besshi-, Cyprus-, and kuroko-type deposits); epithermal vein (includes Comstock-, Creede-, and quartz-adularia-type deposits).

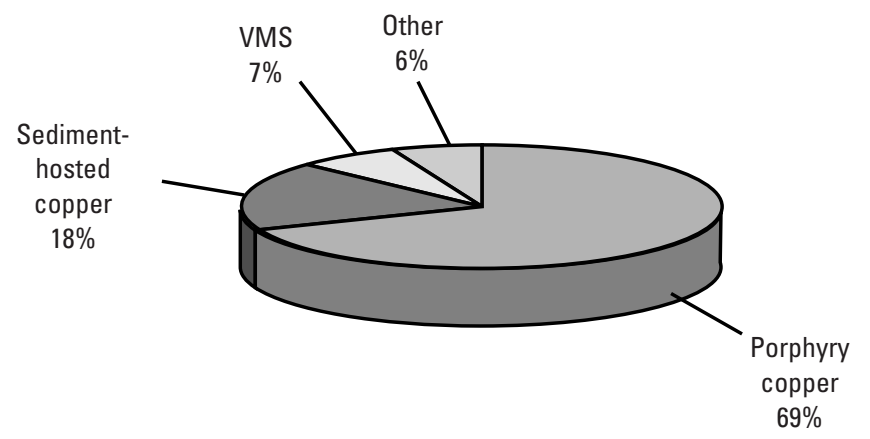

Figure 6. Copper in undiscovered mineral deposits, by major deposit type. VMS, volcanogenic massive sulfide (includes Besshi-, Cyprus-, and kuroko-type deposits).

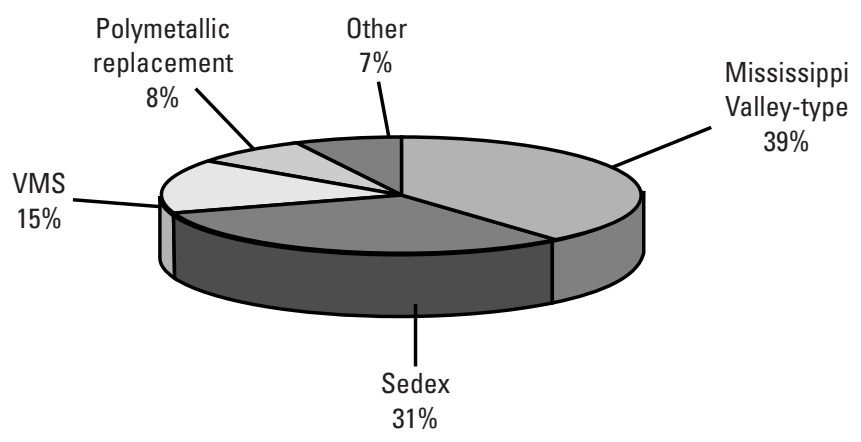

Figure 8. Zinc in undiscovered mineral deposits, by major deposit type. Sedex, sedimentary exhalative; VMS, volcanogenic massive sulfide (includes Besshi-, Cyprus-, and kuroko-type deposits).

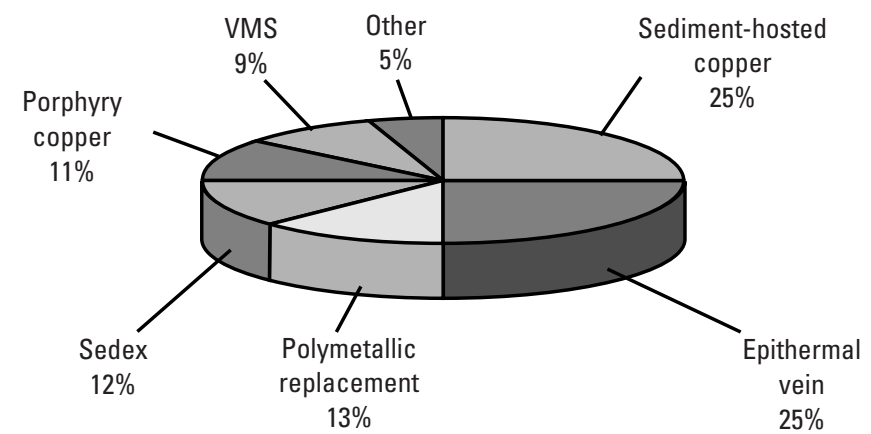

Figure 5. Silver in undiscovered mineral deposits, by major deposit type. Sedex, sedimentary exhalative; VMS, volcanogenic massive sulfide (includes Besshi-, Cyprus-, and kuroko-type deposits); epithermal vein (includes Comstock-, Creede-, and quartz-adularia-type deposits).

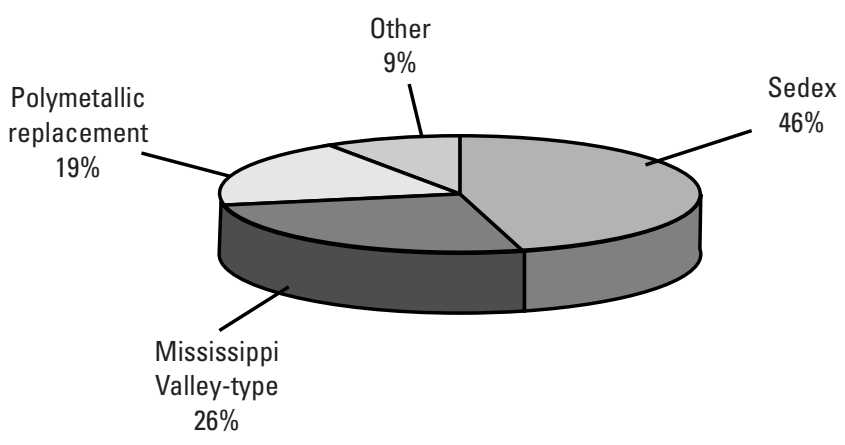

Figure 7. Lead in undiscovered mineral deposits, by major deposit type. Sedex, sedimentary exhalative. 


\section{DISCUSSION AND COMPARISON OF RESULTS WITH THE 1973 NATIONAL MINERAL RESOURCE ASSESSMENT}

As a part of the response to the Mining and Minerals Policy Act of 1970, the USGS published Professional Paper 820 (Brobst and Pratt, 1973), which included the first overall assessment of mineral resources in the United States since the Paley Commission report in 1952 (President's Materials Policy Commission, 1952). Prior to Professional Paper 820, traditional resource appraisals mainly inventoried measured reserves. In the professional paper, the geologic availability of resources that would be needed by future generations was considered for the first time. Each chapter of the professional paper was devoted to a single commodity and was written by geologists, most of whom had many years of experience studying the geology of mineral deposits and the commodity about which they were writing. Because of the large number and varied nature of the commodities that were examined, Brobst and Pratt provided the authors with a suggested outline of general topics to be covered and some guidelines as to scope and philosophy of approach. Beyond that, however, no attempt was made to impose a fixed format. Consequently, the chapters ranged from comprehensive summary reports to general essays. Each chapter reflected the individuality of the authors, as well as such variations among commodities as geologic occurrence, physical and chemical properties, use, and economics. One of the difficulties in interpreting the results of the assessment was the lack of a common method for estimating the amounts of undiscovered resources. Consequently, it was difficult, if not impossible, to disaggregate the estimates provided according to geographic area or by deposit type. Moreover, it was not always possible to gain insight into how the authors arrived at their estimates or to evaluate the level of confidence in the estimates they reported.

Most of the chapters in Professional Paper 820, including those for gold, silver, copper, lead, and zinc, contained summaries of the geologic environment, types of deposits, resources, prospecting techniques, and problems for future research. The authors divided the resources into two categories-identified and undiscovered. Whenever possible, they also divided the undiscovered resources into two categories-hypothetical and speculative. In some cases, the authors further categorized resources according to type of deposit and geographic region of occurrence. Because of the nonuniform and (or) uncertain methods of assessment used by the different authors, it is easiest to compare their results with the 1998 National Mineral Resource Assessment one metal at a time.

\section{GOLD}

According to Simon and Prinz (1973), hypothetical and speculative gold resources, although they could not be estimated as accurately as reserves, were probably large compared with then-current U.S. gold production or consumption but small compared with total world reserves. If one correlates their words with figures for U.S. gold production and total world reserves for 1972, then an estimate of undiscovered gold resources can be obtained that ranges from $56 \mathrm{t}$ to 31,000 $\mathrm{t}$. The largest potential resources of gold were considered to be contained in Tertiary or Cretaceous placer deposits or auriferous conglomerates, followed, in decreasing order of magnitude, by disseminated, lode, "bonanza," and other placer deposits (Simon and Prinz, 1973).

The USGS 1998 mean estimate of $18,000 \mathrm{t}$ of gold in undiscovered deposits, with a range of 13,000 to $22,000 \mathrm{t}$, was well within the range of the 1973 estimate. Even though significant undiscovered gold placer deposits remain in Tertiary or Cretaceous placer deposits in the Northern Rocky Mountain region, the 1998 team was unable to estimate the quantity of gold because of difficulties in applying grade and tonnage concepts. As a result, these potential resources in the Northern Rocky Mountains have been supplanted by potential resources for undiscovered sediment-hosted and hot spring gold deposits in the Great Basin and undiscovered plutonic porphyry gold deposits in Alaska. In addition, it was estimated that the amounts of gold contained in undiscovered porphyry copper deposits in the Basin and Range province and in epithermal vein and low-sulfide gold-quartz vein deposits in the Western United States and Alaska were significant.

\section{SILVER}

Heyl and others (1973) gave an estimate of 68,000 $t$ for the identified resources of silver and 99,000 t for the hypothetical resources of silver. Roughly one-half of their identified resources and less than one-tenth of their hypothetical resources were in deposits in which silver was the main product. With respect to speculative resources, they indicated that the best possibilities for new discoveries were in disseminated copper, porphyry copper, and massive sulfide deposits.

The 1998 mean estimate of 460,000 t of silver in undiscovered deposits and the estimate of 160,000 $t$ of silver in identified resources represent a substantial increase over the 1973 estimates. The increase is due, in large part, to the greater present-day knowledge about the geologic occurrence and distribution of silver-rich sediment-hosted copper deposits and also of epithermal vein and polymetallic replacement deposits. Possibilities of new discoveries that contain significant silver also exist for porphyry copper, sedimentary-exhalative, and volcanogenic massive sulfide deposits. 


\section{COPPER}

Cox and others (1973) gave an estimate of $69,000 \mathrm{kt}$ for the identified resources of copper, $90,500 \mathrm{kt}$ for the hypothetical resources of copper, and 109,000 kt for the speculative resources of copper. Because of the large amount of information available on the copper resources in the United States, they were able to further estimate the amount of copper in the different resource categories according to geographic region and by major deposit type. Table 4 lists the identified and hypothetical copper resources reported by Cox and others (1973).

The hypothetical resources in the Western United States comprised concealed porphyry copper deposits in the Basin and Range province and the Absaroka Range of Wyoming and sedimentary copper deposits in the Belt Supergroup of Idaho and Montana. Alaskan hypothetical resources were considered to include porphyry copper deposits in eastern Alaska and replacement deposits in the Brooks Range.

Table 5 lists the speculative copper resources as reported by Cox and others (1973). They estimated that the greatest likelihood for new discoveries of copper resources was in the American Southwest, primarily in the southwestern, western, and northwestern parts of the Basin and Range province. These areas had not been evaluated as intensively as those in southeastern Arizona where many known porphyry copper deposits in a similar geologic setting have been found. Undiscovered porphyry copper deposits of Paleozoic age were believed to exist in the Appalachian Mountains. Finally, in southwestern Alaska and the Aleutian Islands, geologic conditions were considered to be similar to those of the southwest Pacific, which permitted the occurrence and possible discovery of porphyry copper deposits. Together, the hypothetical and speculative copper resources estimated by Cox and others (1973) totaled 199,500 kt in the United States.

The 1998 mean estimate of the amount of copper in undiscovered deposits of 290,000 kt was roughly one-half again as much as the 1973 estimate. The increase bore out the earlier estimators' optimism for the existence of then-undiscovered porphyry copper deposits in the Southwestern United States. Continuing discoveries of new deposits and extensions of known ones, together with increasingly detailed mapping and exploration, support continuing expectations for further discoveries of these deposits in the region. Additional, more detailed mapping of the Rocky Mountain region also has resulted in expectations of new discoveries of sediment-hosted copper deposits. For the same reasons, British Columbia/Alaska-type porphyry copper deposits probably will be discovered in the Alaskan Range. The discovery of the Crandon massive sulfide deposit in the Lake Superior region in 1976, together with other subsequent discoveries in the region, led to expecta- tions for further discoveries of volcanogenic massive sulfide deposits there.

\section{LEAD}

Morris and others (1973) estimated that hypothetical world lead resources could be equal to one-half or more of world reserves and that the speculative world lead resources could equal or exceed the world reserves. Using world reserves for 1972 as a basis yielded an estimate of undiscovered lead resources for the world of 190,000 kt. Assuming that roughly 30 percent of the world reserves for 1972 were in the United States and that a similar percentage held for undiscovered lead resources in the United States, Morris and others' estimate of the undiscovered lead resources in the United States would translate into 57,000 kt. Morris and others concluded that the areas that held the best promise for new discoveries were located in active or formerly active mining districts, namely, central Tennessee, central and south-central Missouri, northern Arkansas, central Texas, northeastern Washington, and central Kentucky. Deposits have remained undiscovered in these areas either because they are concealed by barren rocks or because insignificant exposures do not indicate their true size or grade.

The 1998 mean estimate of the amount of lead in undiscovered deposits of $85,000 \mathrm{kt}$ was roughly one-half again as much as the estimate of Morris and others (1973). In large part, this increase was due to the discovery of the Red Dog deposit in the Brooks Range, Alaska, and the resulting expectation for further undiscovered sedimentary exhalative deposits throughout Alaska. The rest of the increase was due to the probable existence of undiscovered Mississippi Valley-type deposits in the east-central and northern Appalachian regions.

Table 4. Summary of identified and hypothetical copper resources in the United States, 1973.

[In kilotons. Modified from Cox and others (1973, table 39)]

\begin{tabular}{lrl}
\hline \multicolumn{1}{c}{ Area } & Identified & Hypothetical \\
\hline Eastern ------------ & 9,000 & 4,500 \\
Western, except & & \\
Alaska ----------- & 58,000 & 68,000 \\
Alaska ------------ & 2,000 & 18,000 \\
$\quad$ Total ----------- & 69,000 & 90,500 \\
\hline
\end{tabular}

Table 5. Summary of speculative copper resources in the United States, 1973.

[In kilotons. Modified from Cox and others (1973, table 40)]

\begin{tabular}{|c|c|}
\hline Area & Speculative \\
\hline Basin and Range porphyry copper ------- & 91,000 \\
\hline Alaska porphyry copper ------------- & 9,000 \\
\hline Appalachian Mountains------------------ & 9,000 \\
\hline 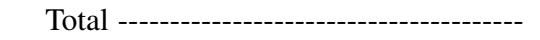 & 109,000 \\
\hline
\end{tabular}




\section{ZINC}

Wedow and others (1973) estimated the recoverable identified zinc resources of the United States to be 45,000 kt and the undiscovered recoverable resources to be $60,000 \mathrm{kt}$. They postulated that the undiscovered or potential resources would be dominated by the massive sulfide ores in metamorphic rocks, in which zinc occurs chiefly with copper and lead, and by the stratabound Mississippi Valley-type deposits in carbonate rocks.

The 1998 mean estimate of the amount of zinc in undiscovered deposits was $210,000 \mathrm{kt}$, which is more than three times the estimate of Wedow and others (1973). In large part, this difference was due to the increased expectation of large resources of zinc that may occur in major undiscovered zinc districts of the Mississippi Valley/Appalachian-type in an area that extends from Tennessee to the Canadian border. The discovery of the Red Dog deposit in the Brooks Range, Alaska, combined with increased exploration in the area, also resulted in increased expectations for future discoveries of sedimentary exhalative deposits throughout Alaska and in parts of the conterminous United States. The balance of the larger estimate was due to the likelihood of further discoveries of volcanogenic massive sulfide deposits in the Lake Superior region, the northern Appalachians, and the Western United States.

\section{SOME CONSIDERATIONS FOR OTHER USES OF THE ASSESSMENT}

Care must be exercised when using the results of the 1998 National Mineral Resource Assessment to answer questions that involve the potential for economic development of the estimated undiscovered resources. These estimates were based on grade and tonnage models, and the present-day economic viability of the deposits used to construct the models varies widely from deposit to deposit, from model to model, and from submodel to submodel. In addition, large parts of the areas delineated as permissive are unavailable for mineral development. Some areas are already being developed as urban areas, transportation corridors, and so forth. Mining and exploration are prohibited by law in the public interest in areas such as Wilderness and Scenic Areas and National Parks. Some areas are owned by those not interested in mineral development.

Estimated amounts of metals contained in undiscovered deposits are derived from estimates of numbers of deposits that are likely to exist, not necessarily from those likely to be discovered. For example, although concealed deposits were included in the assessment, they may be so expensive to search for that they are unlikely to be discovered in the near term.

It also is important to understand the distinctions among identified resources and districts, undiscovered deposits and districts, and extensions to identified resources and districts. An identified deposit or district is one for which an estimate of the metal contained in the deposit can be made directly. The total consists of the sum of past production, if any, and any identified resource remaining in the ground. In some cases, the teams were aware of prospects, revealed by past or current exploration efforts, that were believed to be significant deposits but that did not yet have a documented grade and tonnage. Such deposits are treated herein as undiscovered deposits, albeit ones with a high degree of certainty of existence. Finally, it should be remembered that initial exploration leading to an announced discovery almost never identifies the total resource that exists and (or) ultimately may be mined. As exploration continues and (or) mining begins, an accompanying increase in knowledge about the deposit geology almost always results in increasing estimates of the size of the deposit.

One further note of caution should be given to users of the 1998 National Mineral Resource Assessment. Because the assessment methodology depended on deposit models, the teams were unable to estimate resources in types of deposits that were too poorly characterized for a deposit model to be constructed. An example is the copper-gold deposits in Washington. To better appreciate lack of understanding as a potential source of error in the assessment, imagine such an assessment being completed in 1905 before the recognition of porphyry copper-type deposits or in 1960 before the discoveries of sediment-hosted gold deposits. The consequent underestimation of copper and gold resources would have been so large as to undermine the conclusions about undiscovered resources at the time. Although the United States is much better explored and geologically known now than it was in 1905, new deposit types unimagined today can be expected to contribute substantially to the mineral resources of the United States in the future. Such considerations make it all the more imperative to conduct national assessments on a recurring basis.

\section{EXTENSIONS TO IDENTIFIED RESOURCES}

What are missing from the 1998 National Mineral Resource Assessment are estimates of the amounts of gold, silver, copper, lead, and zinc in extensions to identified resources. Experience shows that almost all estimates of mineral deposit sizes increase during production. Discovery and initial exploration almost never identify the total resource that exists. Mineral producers generally lack the financial incentive to prove reserves in excess of 10 to 20 years production. The exceptions are those cases where pit and plant design or permitting requirements necessitate a complete inventory for the mine plan. Thus, most mining operations actually have lifetimes that are much longer than 
originally reported. Proved reserves increase with normal deposit development as boundaries of proved areas are extended by drilling, as extensions or new deposits are found and confirmed by drilling, as new infill drilling (vertical or horizontal) contacts previously inaccessible portions of the deposit, and with the introduction of improved recovery methods that allow lower grade material to be mined. Because a methodology that takes reserve growth into account is currently lacking, reserve growth is missing from the teams' estimates. The teams, however, believe reserve growth is of the same order of magnitude as that of the identified resources.

\section{IMPLICATIONS}

The 1998 National Mineral Resource Assessment achieved its primary goal - to provide quantitative, probabilistic estimates of the gold, silver, copper, lead, and zinc in undiscovered deposits for the country as a whole. There is every reason to believe that, for conventional-type deposits that contain gold, silver, copper, lead, or zinc, about as much is left to be discovered in the United States as has already been discovered. Furthermore, the method that was used in carrying out the assessment can serve as a guide to assess other commodities of national interest. The data base that was created for the assessment can be useful to land-management agencies and resource-planning organizations for land- and resource-planning and decisionmaking. Such information permits, at least at some minimum level, evaluation of the impact of land-use decisions on the Nation's undiscovered mineral resources. The availability of such a data base provides a unique opportunity for Federal, State, and local governments, industry, and the public to work cooperatively to plan the disposition of the Nation's long-term mineral supply. Federal, State, and local land-management agencies can use the information provided by the assessment to estimate potential cumulative environmental impact of possible exploration and mining activities, to evaluate the potential economic benefits of mining in comparison with other possible land uses, to evaluate and plan for the potential impact of mining activities on other land uses, and to appraise the fair market value of land proposed for leasing, sale, exchange, or taking. The permissive tracts delineated as part of the 1998 National Mineral Resource Assessment permit industry to focus mineral-exploration programs on the most promising areas for discoveries.

Looking to the future, the likelihood of finding new deposits presents new challenges, given that undiscovered deposits do not crop out, access is more difficult, environmental constraints are more severe, landownership is more fragmented, and foreign suppliers are cheaper. If the past can be used as a guide, deposits that are not yet recognized as economic targets, new technologies (for example, biome- diated heap leaching) that might convert formerly discarded rock into ore, or some heretofore unrecognized source of metals (for example, gold in oil-field brines) that would define new targets for exploration are, without a doubt, in the Nation's future. Carrying out national assessments on a recurring basis will ensure adequate mineral supplies and effective stewardship of resources in the future.

\section{REFERENCES CITED}

American Geological Institute, 1997, Dictionary of mining, mineral, and related terms ( $2 \mathrm{~d}$ ed.): Alexandria, Va., American Geological Institute, $646 \mathrm{p}$.

Bliss, J.D., ed., 1992, Developments in mineral deposit modeling: U.S. Geological Survey Bulletin 2004, 168 p.

Brobst, D.A., and Pratt, W.P., eds., 1973, United States mineral resources: U.S. Geological Survey Professional Paper 820, $722 \mathrm{p}$.

Cox, D.P., and Singer, D.A., eds., 1986, Mineral deposit models: U.S. Geological Survey Bulletin 1693, 379 p.

Cox, D.P., Schmidt, R.G., Vine, J.D., Kirkemo, Harold, Tourtelot, E.B., and Fleischer, Michael, 1973, Copper, in Brobst, D.A., and Pratt, W.P., eds., United States mineral resources: U.S. Geological Survey Professional Paper 820, p. 163-190.

Heyl, A.V., Hall, W.E., Weissenborn, A.E., Stager, H.K., Puffett, W.P., and Reed, B.L., 1973, Silver, in Brobst, D.A., and Pratt, W.P., eds., United States mineral resources: U.S. Geological Survey Professional Paper 820, p. 581-603.

Hollister, V.F., 1992, On a proposed plutonic porphyry gold deposit model: Nonrenewable Resources, v. 1, no. 4, p. 293302.

Long, K.R., DeYoung, J.H., Jr., and Ludington, S.D., 1998, Data base of significant deposits of gold, silver, copper, lead, and zinc in the United States; pt. A, Data base description and analysis; pt. B, Digital data base: U.S. Geological Survey Open-File Report 98-206, 33 p., one 3.5-inch diskette.

McCammon, R.B., and Briskey, J.A., Jr., 1992, A proposed national mineral-resource assessment: Nonrenewable Resources, v. 1, no. 4, p. 259-266.

McKelvey, V.E., 1972, Mineral resource estimates and public policy: American Scientist, v. 60, no. 1, p. 32-40.

Morris, H.T., Heyl, A.V., and Hall, R.B., 1973, Lead, in Brobst, D.A., and Pratt, W.P., eds., United States mineral resources: U.S. Geological Survey Professional Paper 820, p. 313-332.

President's Materials Policy Commission, 1952, Resources for freedom: Washington, U.S. Government Printing Office, 5 v., $818 \mathrm{p}$.

Root, D.H., Menzie, W.D., III, and Scott, W.A., 1992, Computer Monte Carlo simulation in quantitative resource assessment: Nonrenewable Resources, v. 1, no. 2, p. 125-138.

Root, D.H., Scott, W.A., Jr., and Selner, G.I., 1997, Computer program for aggregation of probabilistic assessments of mineral resources: U.S. Geological Survey Open-File Report 96-94, 1 diskette.

Simon, F.S., and Prinz, W.C., 1973, Gold, in Brobst, D.A., and Pratt, W.P., eds., United States mineral resources: U.S. Geological Survey Professional Paper 820, p. 263-275. 
Singer, D.A., 1993, Basic concepts in three-part quantitative assessments of undiscovered mineral resources: Nonrenewable Resources, v. 2, no. 2, p. 69-81.

1995, World class base- and precious-metal deposits-A quantitative analysis: Economic Geology, v. 90, no. 1, p. 88104.

U.S. Bureau of Mines and U.S. Geological Survey, 1980, Principles of a resource/reserve classification for minerals: U.S. Geological Survey Circular 831, 5 p.
U.S. Geological Survey, 1998, Mineral Commodity Summaries: U.S. Geological Survey, 197 p.

Wedow, H., Jr., Kiilsgaard, T.H., Heyl, A.V., and Hall, R.B., 1973, Zinc, in Brobst, D.A., and Pratt, W.P., eds., United States mineral resources: U.S. Geological Survey Professional Paper 820, p. 697-711. 


\section{MEMBERS OF THE U.S. GEOLOGICAL SURVEY 1998 NATIONAL MINERAL RESOURCE ASSESSMENT TEAM}

Project Chief-Richard B. McCammon

Editors

Conterminous United States

Steve Ludington

Dennis P. Cox

Alaska-Thomas D. Light

Eastern United States-Sandra H.B. Clark

Western United States-Michael F. Diggles

Central United States-Alan R. Wallace

Southern Basin and Range-Leslie J. Cox

Pacific Coast—Stephen E. Box

Methodology

Donald A. Singer

Lawrence J. Drew

William D. Menzie, II

Mathematician-David H. Root

GIS Compilers

Esther L. Castellanos

Leslie J. Cox

Pamela D. Derkey

James Hall

Garry E. Klein

Devon Peterson

Martin L. Sorenson

GIS and CD-ROM Managers

Paul G. Schruben

Thomas D. Light

Barry C. Moring

David M. Sutphin

Computing and Programming

William A. Scott, Jr.

Susan H. Garcia

Significant Deposits Editors

Keith R. Long

John H. DeYoung, Jr.

Steve Ludington

Dan L. Mosier

Significant Deposits Compilers

James D. Bliss

Arthur A. Bookstrom

Sandra H.B. Clark

Leslie J. Cox

Carl A. Carlson

Warren C. Day

Russell C. Evarts

David Frishman

Robert J. Kamilli

Lorre A. Moyer

Chris Osterman

Miles L. Silberman
Significant Deposits Compilers-Continued Anna B. Wilson

Region Teams

Northern Appalachians

Sandra H.B. Clark

Robert A. Ayuso

Joseph A. Briskey, Jr.

Dennis P. Cox

Michael P. Foose

John J. Hemley

Bruce R. Lipin

John D. Peper

Gilpin R. Robinson, Jr.

John F. Slack

Adirondack Mountains

Sandra H.B. Clark

Joseph A. Briskey, Jr.

C. Ervin Brown

Dennis P. Cox

Michael P. Foose

John F. Slack

Southern Appalachians

Terry L. Klein

Joseph A. Briskey, Jr.

Sandra H.B. Clark

Dennis P. Cox

Jacob E. Gair

Robert P. Koeppen

Frank G. Lesure

Bruce R. Lipin

Terry W. Offield

John D. Peper

Gilpin R. Robinson, Jr.

John F. Slack

Lake Superior

Klaus J. Schulz

William F. Cannon

Michael P. Foose

Martin B. Goldhaber

Terry L. Klein

Gene L. LaBerge

David L. Leach

David A. Lindsey

Suzanne W. Nicholson

Walden P. Pratt

Paul K. Sims

Gregory T. Spanski

John G. Viets

Laurel G. Woodruff 
Region Teams-Continued

East-central

Sandra H.B. Clark

Joseph A. Briskey, Jr.

Dennis P. Cox

John D. Peper

Howard A. Pohn

John F. Slack

Great Plains

Walden P. Pratt

Dennis P. Cox

Warren C. Day

Martin B. Goldhaber

David L. Leach

David A. Lindsey

Gary B. Sidder

Gregory T. Spanski

John G. Viets

Michael L. Zientek

Northern Rocky Mountains

Michael L. Zientek

Byron R. Berger

Arthur A. Bookstrom

Stephen E. Box

Dennis P. Cox

Warren C. Day

James E. Elliott

David Frishman

W. Dan Hausel

David A. Lindsey

Steve Ludington

J. Thomas Nash

Gregory T. Spanski

Alan R. Wallace

James W. Whipple

Central and Southern Rocky Mountains

Steve Ludington

Susan B. Bartsch-Winkler

Byron B. Berger

Dennis P. Cox

Warren C. Day

W. Dan Hausel

David A. Lindsey

Virginia T. McLemore

J. Thomas Nash

Gary B. Sidder

Miles L. Silberman

Gregory T. Spanski

Alan R. Wallace

Michael L. Zientek

Colorado Plateau

David A. Lindsey

Dennis P. Cox

Michael L. Zientek
Region Teams-Continued

Pacific Coast

Stephen E. Box

George V. Albino

Roger P. Ashley

Arthur A. Bookstrom

Stanley E. Church

Dennis P. Cox

Michael F. Diggles

James G. Evans

Russell C. Evarts

Merlin D. Kleinkopf

Steve Ludington

Stephen G. Peters

James A. Peterson

William J. Pickthorn

Gary Lee Raines

James J. Rytuba

Michael G. Sawlan

Gregory T. Spanski

Richard M. Tosdal

Great Basin

Dennis P. Cox

George V. Albino

Roger P. Ashley

Byron R. Berger

Stanley E. Church

Ed H. DeWitt

Michael F. Diggles

Merlin D. Kleinkopf

David A. Lindsey

Steve Ludington

J. Thomas Nash

Constance J. Nutt

James J. Rytuba

Michael G. Sawlan

Maureen G. Sherlock

Donald A. Singer

Gregory T. Spanski

Douglas B. Stoeser

Joseph V. Tingley

Alan R. Wallace

Michael L. Zientek

Southern Basin and Range

Leslie J. Cox

William C. Bagby

Susan B. Bartsch-Winkler

Byron R. Berger

Carl A. Carlson

Stanley E. Church

Dennis P. Cox

Michael F. Diggles

Frederick S. Fisher

Eric R. Force

James Guthrie 
Region Teams-Continued

Southern Basin and Range-Continued

Robert C. Jachens

Robert J. Kamilli

Merlin D. Kleinkopf

Steve Ludington

Virginia T. McLemore

J. Thomas Nash

Stephen G. Peters

James J. Rytuba

Michael G. Sawlan

Miles L. Silberman

Donald A. Singer

Gregory T. Spanski

Ted G. Theodore

Spencer R. Titley

Richard M. Tosdal

Alan R. Wallace

Alaska

Brooks Range

Jeanine M. Schmidt

Byron R. Berger

John W. Cady

Lawrence J. Drew

Karen A. Duttweiler

Richard I. Grauch

Karen D. Kelley

James E. Kilburn

Gregory T. Spanski

East-central

Donald J. Grybeck

Byron R. Berger

Thomas K. Bundtzen

John W. Cady

Stanley E. Church

Dennis P. Cox

Robert G. Eppinger

Bruce M. Gamble

William J. Keith

Gregory K. Lee

Thomas D. Light

Marti L. Miller

Warren J. Nokleberg

Jeffrey D. Phillips

Jeanine M. Schmidt

Gregory T. Spanski

West-central

Bruce M. Gamble

Byron R. Berger

Thomas K. Bundtzen

John W. Cady

Stanley E. Church

Dennis P. Cox

Robert G. Eppinger

John E. Gray
Region Teams-Continued

Alaska-Continued

West-central-Continued

Thomas D. Light

Marti L. Miller

Jeffrey D. Phillips

Richard W. Saltus

Jeanine M. Schmidt

Gregory T. Spanski

Frederic H. Wilson

Southeastern

David A. Brew

David F. Barnes

Lawrence J. Drew

James L. Drinkwater

Donald J. Grybeck

Robert C. Jachens

Richard D. Koch

Cliff D. Taylor

South-central

Warren J. Nokleberg

Thomas K. Bundtzen

David L. Campbell

Dennis P. Cox

Bruce M. Gamble

Richard J. Goldfarb

Donald J. Grybeck

William J. Keith

Gregory K. Lee

Thomas D. Light

Marti L. Miller

Jeffrey D. Phillips

Jeanine M. Schmidt

Warren E. Yeend

Southwestern

Marti L. Miller

Thomas K. Bundtzen

John W. Cady

Stanley E. Church

Dennis P. Cox

Lawrence J. Drew

Robert G. Eppinger

Bruce M. Gamble

John E. Gray

William D. Menzie, II

Warren J. Nokleberg

Jeffrey D. Phillips

Richard W. Saltus

Jeanine M. Schmidt

Frederic H. Wilson

Alaska Peninsula and the Aleutians

Frederic H. Wilson 
Region Teams-Continued

Alaska-Continued

Alaska Peninsula and the Aleutians-

Continued

Stanley E. Church

Lawrence J. Drew

W. David Menzie, II

Richard W. Saltus
National reviewers

Paul B. Barton

Paul K. Sims

Alaska reviewers

Paul B. Barton

Henry C. Berg

Donald H. Richter 


\section{About the Compact Disc \\ 1998 Assessment of Undiscovered Deposits of Gold, Silver, Copper, Lead, and Zinc in the United States- \\ CD-ROM Containing Circular Report, Data Base, and Graphical Display Program}

The data base of the tracts that were used to generate the resource estimates obtained in the National Mineral Resource Assessment is stored on a Compact Disc-Read Only Memory (CD-ROM), which is included in a pocket at the end of this report. The CDROM also contains this circular and a browser that can be used to examine the tracts by region and by major deposit model type and the significant mineral deposits that occur in the tracts. The data base consists of the following:

- Estimates of the tonnages and amounts of contained metal in undiscovered deposits,

- A table that lists the mineral deposit model types used in the National Mineral Resource Assessment,

- A table that lists the tonnages and amounts of contained metal in the significant mineral deposits in the United States,

- The rationale that was used to assess each of the tracts in the National Mineral Resource Assessment, and

- A list of references for each tract in the National Mineral Resource Assessment.
The browser is a map-based, stand-alone Windows application that can be installed from the CDROM. The browser allows a user to click on a tract for a selected mineral deposit model type and to display either the tabular data associated with the tract or the rationale that was used to assess the tract. The rationale contains hypertext links to the tonnage and amounts of contained metal in undiscovered deposits, the mineral deposit model type used to assess the particular tract, and the significant mineral deposits associated with the tract. A user can also choose to display the assessment regions, mining districts, and significant mineral deposits, as well as several standard thematic layers such as political boundaries, cities, airports, rivers, and color-shaded relief.

This CD-ROM was produced in accordance with the ISO 9660 Level 2 standard. The included browser installs only under Windows 95, 98, or NT operating systems.

To get started: Launch the "NASetup.exe" program in the main directory of the disc. It installs a Start menu item called "National Assessment." 
